\title{
Investigation of the effects of machining parameters on tool life and surface roughness during the face milling of the NiTi shape memory alloy with uncoated tools
}

\author{
Emre Altas $^{1, *}$, Hasan Gokkaya ${ }^{2}$ and Dervis Ozkan ${ }^{1}$ \\ ${ }^{1}$ Department of Mechanical Engineering, Bartin University, Bartin, Turkey \\ ${ }^{2}$ Department of Mechanical Engineering, Karabük University, Karabük, Turkey \\ *Correspondence: emrealtas@bartin.edu.tr or emrealtas2540@gmail.com; Tel.: +90 3785011000
}

\begin{abstract}
Shape memory alloys (SMAs) are increasingly used in the fields of aviation, automotive and biomedicine due to their unique properties. Nickel-Titanium (NiTi) alloy materials, which are one of the shape memory alloys, are among the most frequently used alloy materials. The shape memory and super elastic effects of NiTi alloys, high ductility and deformation hardening make it difficult to shape burr. An additional problem is the formation of a white layer during machining. In this study, surface milling operations were performed in dry cutting conditions with uncoated cutting tools with different nose radii. The processing parameters were determined based on the experience gained as a result of the preliminary tests. Tungsten carbide cutting tools with different nose radii $(0.4 \mathrm{~mm}$ and $0.8 \mathrm{~mm})$ were used for the milling operations. Milling was carried out at three different cutting speeds $(20,35,50 \mathrm{~m} / \mathrm{min})$, feed rates $(0.03,0.07,0.14 \mathrm{~mm} /$ tooth $)$, and a constant axial cutting depth $(0.7 \mathrm{~mm})$. As a result of our experimental studies, the best tool life was found to be in $0.8 \mathrm{~mm}$ nose radius cutting tools at $20 \mathrm{~m} / \mathrm{min}$ cutting speed and $0.03 \mathrm{~mm} /$ tooth feed rate $(0.264 \mathrm{~mm})$. The minimum average surface roughness was found after milling with $0.8 \mathrm{~mm}$ nose radius cutting tool at $20 \mathrm{~m} / \mathrm{min}$ cutting speed and $0.03 \mathrm{~mm} /$ tooth feed rate $(0.346 \mu \mathrm{m})$. It has been determined that increasing the cutting tool nose radius reduces both the flank wear over the cutting tool and the average surface roughness.
\end{abstract}

Keywords: NiTi shape memory alloy; cutting tool life; surface roughness; face milling.

\section{Introduction}

In daily life, the demand for more functional products due to the problems encountered in the fields of medicine and industry caused scientists to improve the properties of materials and to produce new materials with superior properties. Smart materials which have made great progress in recent years have the ability to change their properties according to environmental conditions, and they are used to transform one type of energy into another one [1]. The use of smart materials in biomedical, aviation and automotive industries is gradually increasing. Shape memory alloys, which are among smart materials, are the materials that can return to their original form (shape or size) 
when subjected to a recall process between two transformation phases dependent on temperature or magnetic field [2].

$\mathrm{NiTi}$ is the most frequently used shape memory alloy in biomedical field. The most important difference of NiTi shape memory alloy from other engineering materials is its phase transformation when exposed to heat, load or magnetic field. This phase transformation causes the material to have shape memory and return to its original shape with increasing temperature [3]. The NiTi alloy is in martensitic phase at low temperatures and in the austenitic phase at high temperatures [4]. A review of the literature showed that different manufacturing processes are used for the machining of NiTi alloy such as laser processing method [5-16], electrical discharge machining (EDM) [17- 31], electrochemical polishing [32] and abrasive water jet processing method (AWJM) [33, 34] for shaping NiTi alloy and also conventional machining methods (Turning [35-50], milling [4, 5, 51-58] and drilling [50, 59-61]. The short lifetime of the cutting tools, burr and white layer formation are the problems encountered in machining of NiTi shape memory alloy. All these problems are due to the shape memory effect, super elasticity effects, high ductility and large deformation hardening. Therefore, the machining of such alloys is difficult [3, 35, 38-45]. NiTi shape memory alloys cause high strain hardening due to the mechanical loads they are exposed to during machining and the high temperatures that occur during cutting. All these factors accelerate the damage caused by flank wear of the cutting tools [39-45]. In addition, the shape memory feature causes the material to have a varying elasticity module during manufacturing process, which affects the machinability of the material and the dimensional accuracy of the final product $[4,49,50,53,60]$.

A review of the literature showed that no studies have yet been conducted on the machining of the NiTi shape memory alloy with cutting tools with different nose radii. In the literature, most of the studies are devoted to micro-milling with carbide end mills. However, conventional milling is used for the manufacturing of large-size plates which are used to join bones in medicine. In this study, surface milling of NiTi shape memory alloy with cutting tools that have different nose radii was investigated at different cutting parameters and under dry cutting conditions. The effect of the cutting tools with two different nose radii on the tool lifetime and surface roughness of workpiece was investigated

\section{Materials and Methods}

\subsection{Test Specimens}

The NiTi shape memory alloy used for joining the broken bones in the field of orthopedics has been used as a workpiece. The NiTi alloy was produced using the vacuum arc melting (VAM) method and then was subjected to hot rolling. It was in the austenite phase at room temperature. The

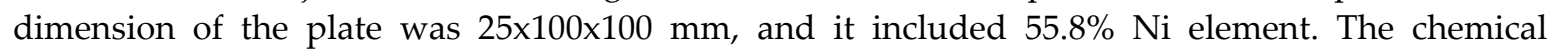
composition of the NiTi shape memory alloy is given in Table 1 and the mechanical properties are given in Table 2.

Table 1. The chemical composition of NiTi shape memory alloy (Weight \%).

\begin{tabular}{cccccccccc}
\hline $\mathrm{Ni}$ & $\mathrm{C}$ & $\mathrm{Co}$ & $\mathrm{Cu}$ & $\mathrm{Cr}$ & $\mathrm{H}$ & $\mathrm{Fe}$ & $\mathrm{Nb}$ & $\mathrm{N}+\mathrm{O}$ & $\mathrm{Ti}$ \\
\hline 55.8 & 0.038 & 0.005 & 0.006 & 0.004 & 0.001 & 0.0012 & 0.005 & 0.041 & 44.09 \\
\hline
\end{tabular}

Table 2. Mechanical properties of NiTi shape memory alloy

\begin{tabular}{cccc}
\hline Yield Strength, (MPa) & Tensile Strength, (MPa) & \%Elongation & $\begin{array}{c}\text { Hardness, } \\
\text { (HRC) }\end{array}$ \\
\hline 210 & 783 & 16.5 & 26.5 \\
\hline
\end{tabular}


The phase transformation temperatures of the alloy were measured using the differential scanning calorimetry (DSC) method (see Table 3). The phase transformation temperature values in Table 3 show that NiTi alloy was in the austenite phase at room temperature before processing

Table 3. Phase transformation temperatures of NiTi shape memory alloy.

\begin{tabular}{lcccccc}
\hline Melting Method & $\begin{array}{c}\text { Surface } \\
\text { Treatment }\end{array}$ & $\begin{array}{c}\text { Heat } \\
\text { Treatment }\end{array}$ & $\begin{array}{c}\text { Mf } \\
\left({ }^{\circ} \mathrm{C}\right)\end{array}$ & $\begin{array}{c}\text { Ms } \\
\left({ }^{\circ} \mathrm{C}\right)\end{array}$ & $\begin{array}{r}\text { As } \\
\left({ }^{\circ} \mathrm{C}\right)\end{array}$ & $\begin{array}{r}\text { Af } \\
\left({ }^{\circ} \mathrm{C}\right)\end{array}$ \\
\hline Vacuum Arc Method & Hot Rolling & Annealed & -49.87 & -10.95 & -32.99 & 8.79 \\
\hline
\end{tabular}

\subsection{Cutting Tools and Machining Parameters}

In the milling of NiTi shape memory alloys, uncoated changeable tungsten carbide cutting tools with $0.8 \mathrm{~mm}$ nose radius of R39011T308E (NLH13A) quality and $0.4 \mathrm{~mm}$ nose radius of R39011T304E (NLH13A) quality produced by the Sandvik Coromant Company were used. To ensure the same conditions in all experiments, a new cutting tool was used in each test. After each test, the bench was stopped, the cutting speed and feed rate were changed, and a total of 18 experiments were carried out, with 9 experiments for each type of cutting tool with different nose radii. The geometric dimensions of the cutting tools determined in accordance with ISO 1832 are given in Figure 1.

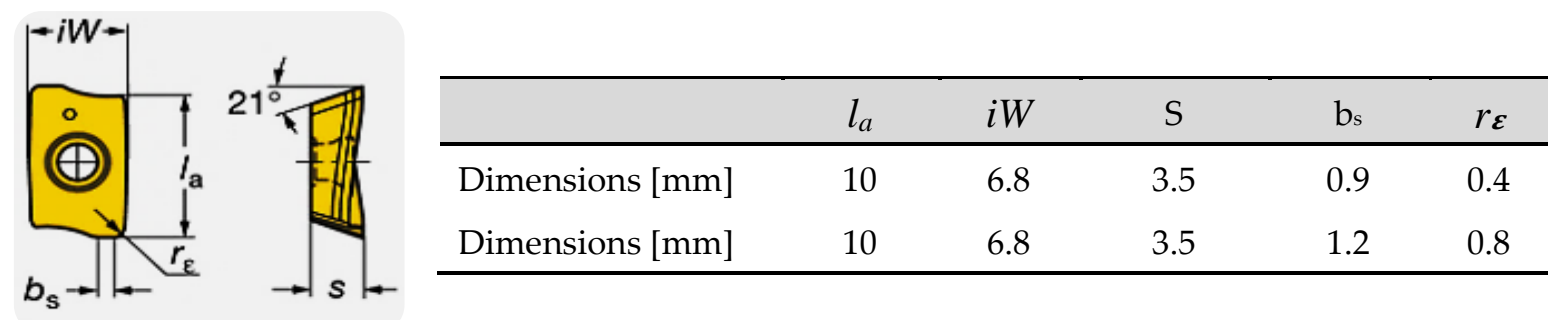

Figure 1. The geometric dimensions of milling cutting tools [62].

Two-blade tool holder R390-025A25-11L, suitable for changeable tools, was used in the experiments. The tool holder was selected according to ISO 5608. In order to provide constant machining parameters, the experiments were carried out by installing only one cutting tool on the tool holder. While determining the machining parameters, three different cutting speeds, feed rates and constant axial cutting depth values were determined based on the experience gained as a result of preliminary tests and considering the values recommended by both ISO 1832 and the manufacturers for the $0.4 \mathrm{~mm}$ and $0.8 . \mathrm{mm}$ nose radii for cutting tools. The machining parameters used in cutting tests are given in Table 4 .

Table 4. Cutting tools and machining parameters for milling.

\begin{tabular}{cccc}
\hline Parameters & Level 1 & Level 2 & Level 3 \\
\hline (Vc) Cutting speed (m/min) & 20 & 35 & 50 \\
(fz) Feed rate (mm/tooth) & 0.03 & 0.07 & 0.14 \\
(ap) Axial depth of cut (mm) & 0.7 & & \\
(re) Nose radius of tungsten & & & \\
carbide cutting tools (mm) & 0.4 & 0.8 &
\end{tabular}


(ae) Radial depth of cut (mm) 15

2.3. Milling Machine, Surface Roughness Measuring Instrument, and Scanning Electron Microscope (SEM) Device

For chip removal operations, a triaxial "Falco VMC 855-B" industrial CNC milling machine with a power of $10 \mathrm{~kW}$ was used. The general view of the milling process is shown in Figure 2.

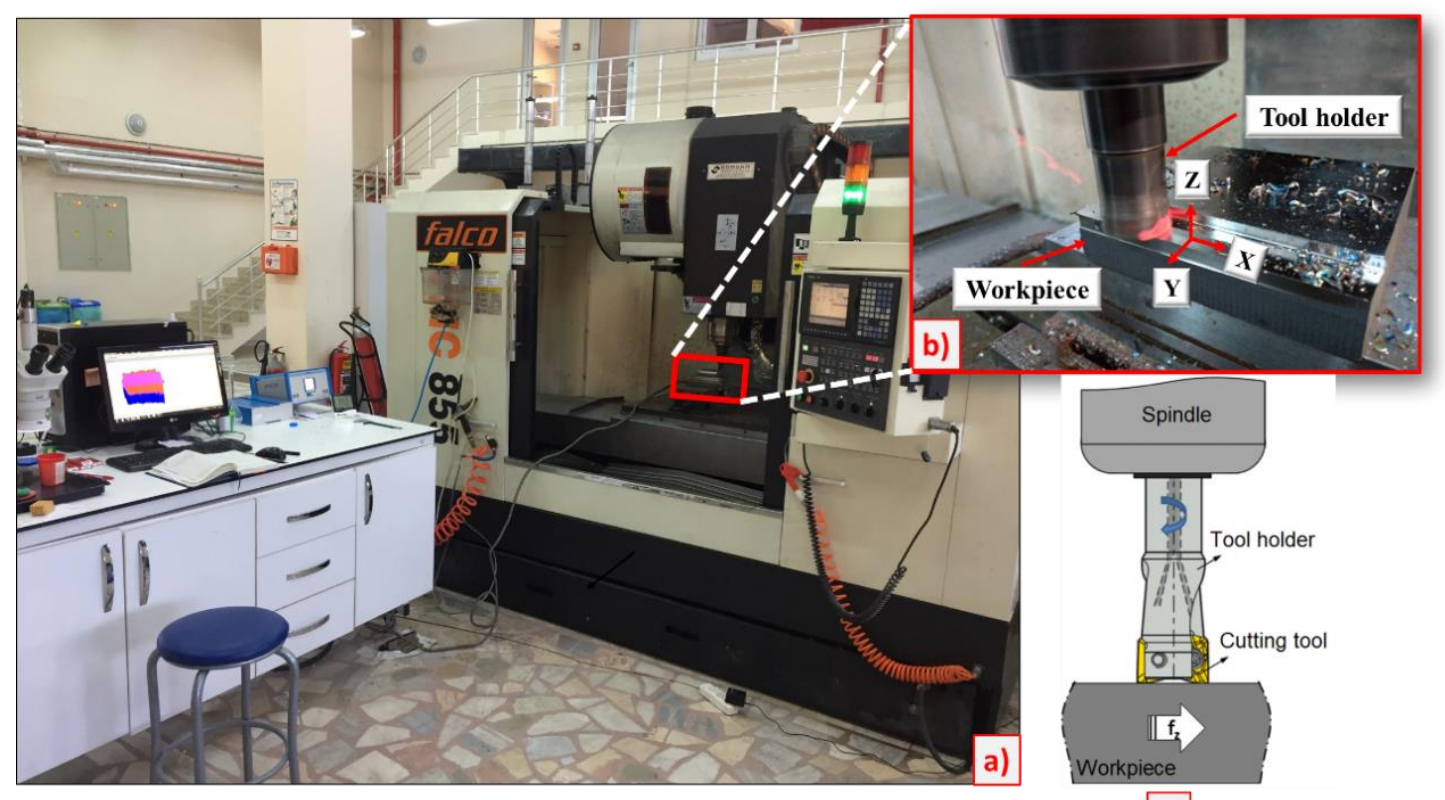

c)

Figure 2. a) The milling machine used in cutting tests b) the general view of the experimental setup c) the photographic representation of the surface milling process.

The amount of cutting tool wear and the surface roughness ( $\mathrm{Ra}$ ) of the workpiece were measured at the end of each $100 \mathrm{~mm}$ of cutting length of the tool during the cutting process. The measurement of the workpiece surface roughness was performed after each cutting depth removed from the surface. After each test, the cutting operation was paused, the cutting tool was removed from the tool holder and the depth of tool wear was measured using an optical microscope. During the cutting tests, a CCD camera mounted on the Vision SX45 stereo zoom optical microscope was used to measure the amount of flank wear (VB) that occurs on the cutting tools. According to the surface milling standard TS ISO 8688-1, the amount of wear on the free surface of the cutting tool is predicted to be $0.3 \mathrm{~mm}$ [63]. The wear mechanism on the cutting tools was examined using the FEI Quanta FEG 250 type scanning electron microscope (SEM) and energy dispersing spectroscope (EDS). The Mitutoyo Surftest SJ-310 tipped surface roughness device was used to measure surface roughness (Figure 3). After each cutting process, the roughness values taken from three different points over the machined workpiece surface were recorded. The average surface roughness ( $\mathrm{Ra}$ ) was determined by calculating the arithmetic mean of the three values. The cut-off length and the sampling length were taken as $0.8 \mathrm{~mm}$ and $5.6 \mathrm{~mm}$, respectively for the measurement of the workpiece surface roughness. The ambient temperature was $20 \pm 1{ }^{\circ} \mathrm{C}$. 


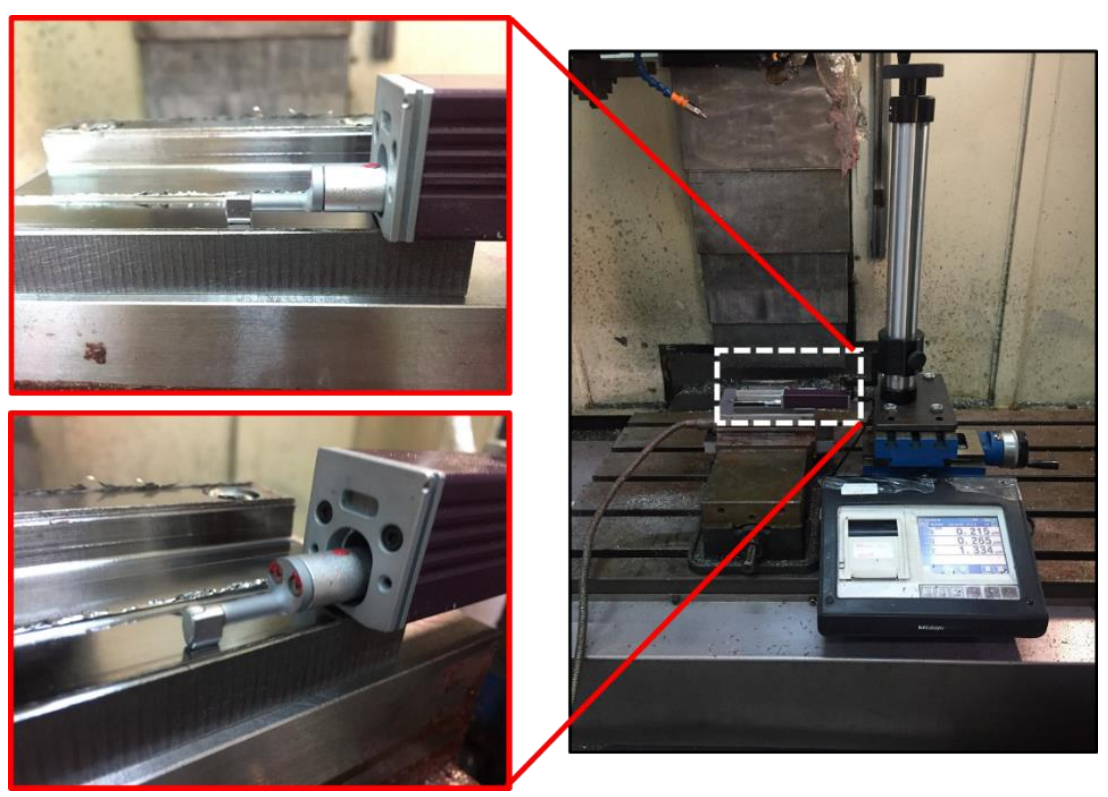

Figure 3. The image of surface roughness measurement on three different points of NiTi shape memory alloy performed using the Mitutoyo Surftest SJ-310 tipped surface roughness device.

\section{Results and Discussion}

\subsection{Change in Surface Roughness due to Cutting Speed and Feed Rate}

The surface roughness values obtained in three different cutting speeds and feed values with uncoated tungsten carbide tools with two different nose radii are given in Table 5 . When the surface roughness values obtained at different cutting speeds were examined, it was observed that the lowest surface roughness was in the chip removal performed at a cutting speed of $20 \mathrm{~m} / \mathrm{min}$ with a cutting tool with $0.8 \mathrm{~mm}$ nose radius and as cutting speed increased, the surface roughness increased as well. The lowest surface roughness was obtained with the cutting tool with a nose radius of $0.8 \mathrm{~mm}$ and a feed rate of $0.03 \mathrm{~mm} /$ tooth.

Table 5. Surface roughness values obtained at different nose radii, cutting speed and feed rate.

\begin{tabular}{|c|c|c|c|c|c|c|c|}
\hline $\begin{array}{c}\text { Test } \\
\text { No }\end{array}$ & $\begin{array}{c}\text { Nose } \\
\text { Radius } \\
\text { (re) }\end{array}$ & $\begin{array}{c}\text { Cutting } \\
\text { Tool }\end{array}$ & $\begin{array}{c}\text { Cutting } \\
\text { Speed } \\
\text { Vc } \\
(\mathrm{m} / \mathrm{min})\end{array}$ & $\begin{array}{c}\text { Feed Rate } \\
\text { fz } \\
(\mathrm{mm} / \text { tooth) }\end{array}$ & $\begin{array}{c}\text { Axial } \\
\text { Depth Of } \\
\text { Cut } \\
\text { ap (mm) }\end{array}$ & $\begin{array}{c}\text { re: } 0.4 \mathrm{~mm} \\
\text { For Average } \\
\text { Surface } \\
\text { Roughness } \\
\text { Ra }(\mu \mathrm{m})\end{array}$ & $\begin{array}{c}\text { re: } 0.8 \mathrm{~mm} \\
\text { For Average } \\
\text { Surface } \\
\text { Roughness } \\
\text { Ra }(\mu \mathrm{m})\end{array}$ \\
\hline 1 & \multirow[b]{5}{*}{$0.4 \mathrm{~mm}$} & \multirow{5}{*}{$\begin{array}{l}\text { Uncoated } \\
\text { Tungsten } \\
\text { Carbide }\end{array}$} & \multirow{3}{*}{20} & 0.03 & \multirow{5}{*}{0.7} & 0.424 & 0.346 \\
\hline 2 & & & & 0.07 & & 0.522 & 0.381 \\
\hline 3 & & & & 0.14 & & 0.645 & 0.538 \\
\hline 4 & & & \multirow[b]{2}{*}{35} & 0.03 & & 0.612 & 0.519 \\
\hline 5 & & & & 0.07 & & 0.678 & 0.554 \\
\hline
\end{tabular}




\begin{tabular}{|c|c|c|c|c|c|}
\hline 6 & & & 0.14 & 0.692 & 0.572 \\
\hline 7 & \multirow[t]{3}{*}{$0.8 \mathrm{~mm}$} & \multirow{3}{*}{50} & 0.03 & 0.546 & 0.384 \\
\hline 8 & & & 0.07 & 0.615 & 0.420 \\
\hline 9 & & & 0.14 & 0.736 & 0.585 \\
\hline
\end{tabular}

Figure 4 shows the workpiece surface roughness values that emerge as a result of the machining of the NiTi shape memory alloy with $0.4 \mathrm{~mm}$ nose radius tungsten carbide tools at three different cutting speeds and feed rates. The highest surface roughness was obtained with the cutting speed of $50 \mathrm{~m} / \mathrm{min}$ and a feed rate of $0.14 \mathrm{~mm} /$ tooth $(0.736 \mu \mathrm{m})$, while the lowest surface roughness was achieved with the cutting speed of $20 \mathrm{~m} / \mathrm{min}$ and a feed rate of $0.03 \mathrm{~mm} /$ tooth $(0.424 \mu \mathrm{m})$. As we can see from the graph in Figure 4, the values of surface roughness are $0.530 \mu \mathrm{m}$ at $20 \mathrm{~m} / \mathrm{min}, 0.632 \mu \mathrm{m}$ at $50 \mathrm{~m} / \mathrm{min}$, and $0.660 \mu \mathrm{m}$ at $35 \mathrm{~m} / \mathrm{min}$ from lowest to highest. It is known from the literature that with a higher cutting speed, the surface roughness of the workpiece can be reduced [70-75]. The reason for lower surface roughness at lower cutting speeds (less than $20 \mathrm{~m} / \mathrm{min}$ ) may be attributed to the BUE that is formed on the cutting tool, which increases the nose radius [38-45]. The scanning electron microscope (SEM) image of BUE that is formed on the cutting tool at $20 \mathrm{~m} / \mathrm{min}$ cutting speed is shown in Figure $5 \mathrm{a}$. At a certain cutting speed $(35 \mathrm{~m} / \mathrm{s})$, surface roughness reaches the maximum value, and then decreases again. This surface roughness decrease can be explained by less deformation hardening, better deforming of the workpiece material around the cutting edge and nose radius due to the increasing temperature at high cutting speed, and the flow zone formed at these high temperatures [70 -74]. A $4 \%$ decrease in surface roughness $(0.632 \mu \mathrm{m})$ was achieved with a $30 \%$ increase in cutting speed $(50 \mathrm{~m} / \mathrm{min})$. As already mentioned, when cutting speed is increased from 20 $\mathrm{m} / \mathrm{min}$. to $35 \mathrm{~m} / \mathrm{min}$, surface roughness increases. This is a consequence of flank wear (Figure $5 \mathrm{~b}$ ) of cutting tool at high temperature because the friction coefficient increases with cutting speed [40-45, 60-65]. An improvement in surface roughness due to the increase in cutting speeds is an expected result [65-74]. The increase in surface roughness at high cutting speed $(50 \mathrm{~m} / \mathrm{min})$ and feed rate $(0.14$ $\mathrm{mm} /$ tooth) was attributed to the high tool wear on the cutting tool (Figure $4 \mathrm{c}$ ). A $23 \%$ and $24 \%$ change was observed in surface roughness in the cutting process performed at $20 \mathrm{~m} / \mathrm{min}$ cutting speed and $0.7 \mathrm{~mm}$ constant depth of cut. The lowest surface roughness change was observed when the feed rate was increased from $0.03 \mathrm{~mm} /$ tooth to $0.07 \mathrm{~mm} /$ tooth (a $133 \%$ increase). The increase in surface roughness was found to be $23 \% .11 \%$ and $2 \%$ changes were observed in surface roughness values when there was $133 \%$ and $100 \%$ increase in feed rate in the cutting process performed at $35 \mathrm{~m} / \mathrm{min}$ cutting speed and $0.7 \mathrm{~mm}$ constant depth of cut. The lowest surface roughness change was observed when the feed rate was increased from $0.07 \mathrm{~mm} /$ tooth to $0.14 \mathrm{~mm} /$ tooth (a $100 \%$ increase). The increase in surface roughness was determined as $2 \% .13 \%$ and $20 \%$ change was observed in surface roughness values when the feed rate was increased by $133 \%$ and $100 \%$ in the cutting process performed at $50 \mathrm{~m} / \mathrm{min}$. cutting speed and $0.7 \mathrm{~mm}$ constant depth of cut. The lowest surface roughness change was seen when the feed rate was increased from $0.03 \mathrm{~mm} /$ tooth to $0.07 \mathrm{~mm} /$ tooth (a 133\% increase). The increase in surface roughness was determined as $13 \%$. When the effect of cutting speed on surface roughness was examined, the minimum surface roughness was achieved at $20 \mathrm{~m} / \mathrm{min}$ cutting speed $(0.530 \mu \mathrm{m})$.

When the surface roughness values obtained based on the feed rate are examined, the minimum surface roughness was obtained at low feed rate of $0.03 \mathrm{~mm} /$ tooth $(0.527 \mu \mathrm{m})$, while the maximum surface roughness was obtained at high feed rate of $0.14 \mathrm{~mm} /$ tooth $(0.605 \mu \mathrm{m})$. When the surface roughness values in Figure 4 obtained based on the feed rate are examined, the (arithmetic) surface roughness values were $(0.527 \mu \mathrm{m})$ at the lowest feed rate of $0.03 \mathrm{~mm} /$ tooth, $(0.605 \mu \mathrm{m})$ at 0.07 $\mathrm{mm} /$ tooth, and $(0.691 \mu \mathrm{m})$ at $0.14 \mathrm{~mm} /$ tooth from minimum to maximum, respectively. $24 \%$ 
improvement $(0.527 \mu \mathrm{m})$ was observed in surface roughness obtained at a high feed rate $(0.14$ $\mathrm{mm} /$ tooth $)(0.691 \mu \mathrm{m})$ when the feed rate was decreased by $79 \%(0.03 \mathrm{~mm} /$ tooth $)$. Increase in surface roughness depending on the increase in feed rate is theoretically (Equation 1) expected and the feed rate has to be reduced to decrease surface roughness [70-75]. A higher surface roughness value at high feed rate $(0.14 \mathrm{~mm} /$ tooth) may be attributed to tool wear (Figure $4 \mathrm{c})$. The results obtained coincide with those in the literature $[38-45,53]$. The lowest surface roughness $(0.527 \mu \mathrm{m})$ was obtained at $0.03 \mathrm{~mm} /$ tooth feed rate when the effect of feed rates on surface roughness is examined.

$$
R_{a}=\frac{0.321 x f^{2}}{r_{\varepsilon}}
$$

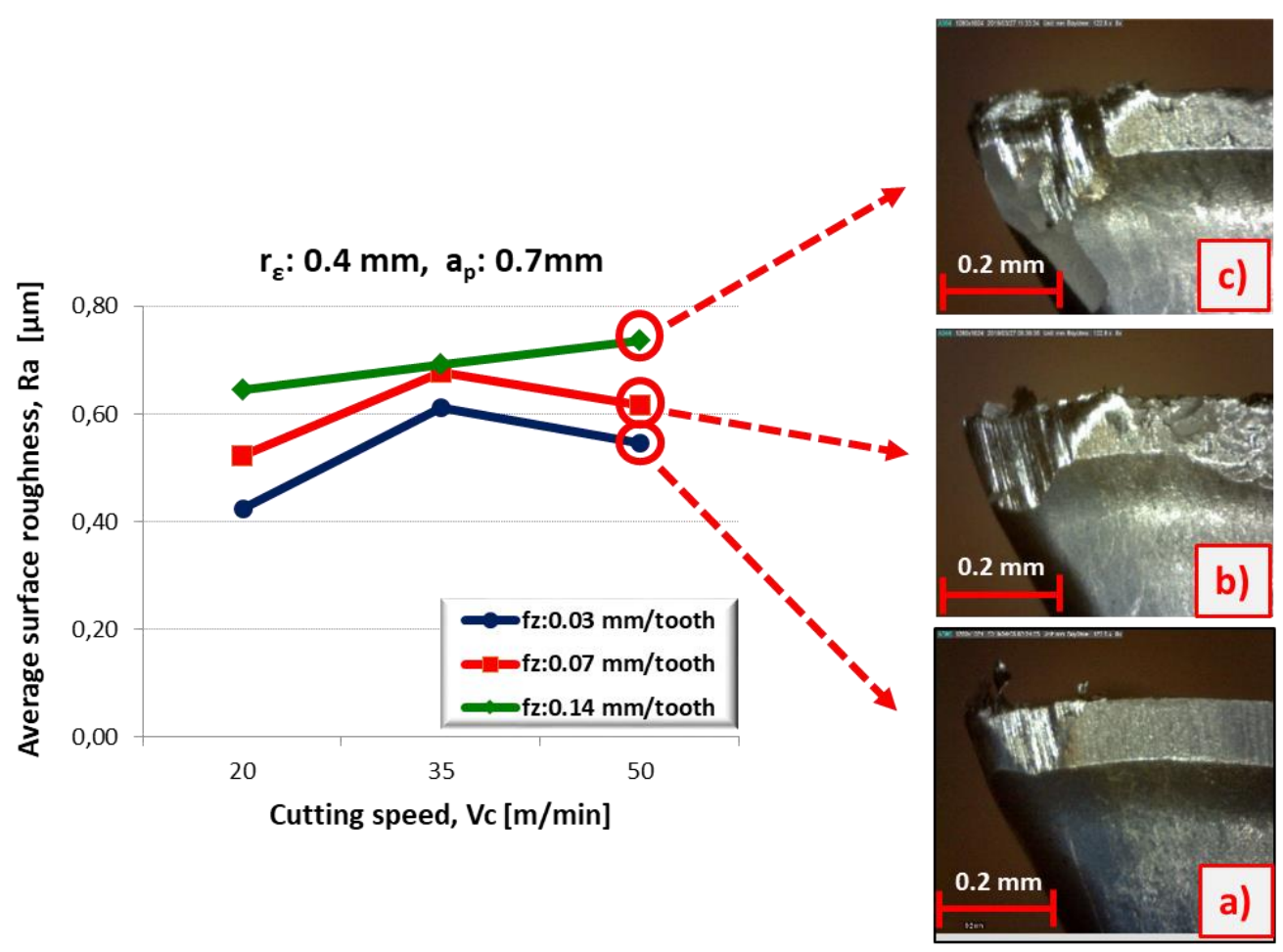

Figure 4. Surface roughness obtained during the machining of the NiTi shape memory alloy with a $0.4 \mathrm{~mm}$ nose radius tungsten carbide at three different cutting speeds (left) and flank wear OM images at high cutting speed (50 m/min) with a) $0.3 \mathrm{~mm} /$ tooth b) $0.07 \mathrm{~mm} /$ tooth and c) $0.14 \mathrm{~mm} /$ tooth (right).
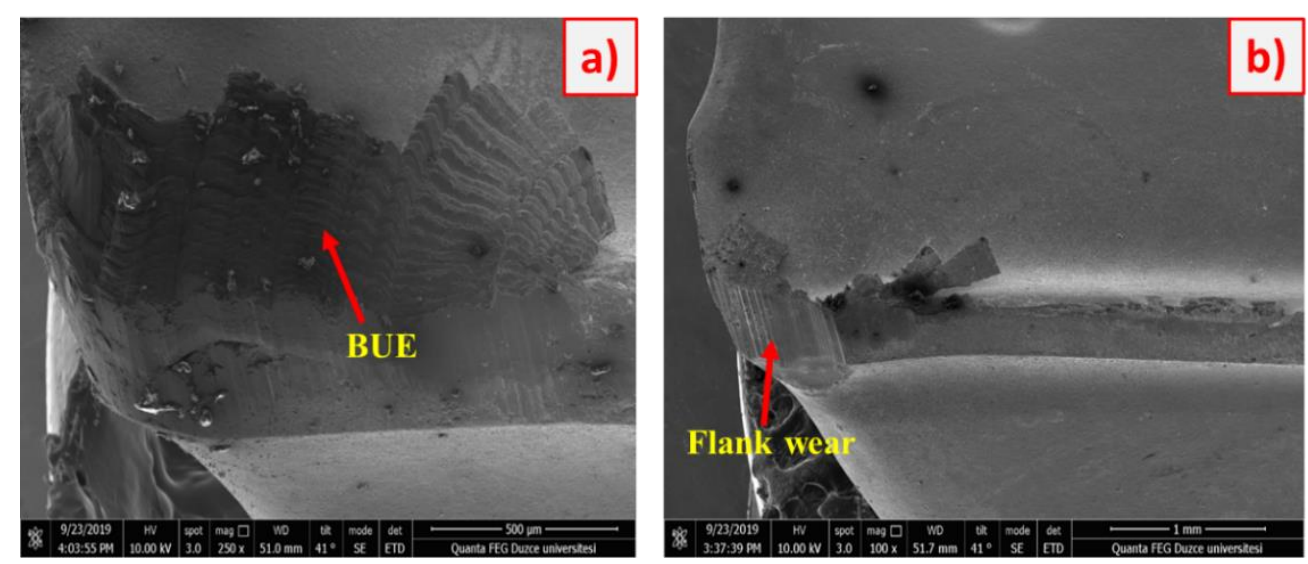
Figure 5. a) The SEM image of BUE that occurred on the cutting tool as a result of the machining of NiTi shape memory alloy with $0.4 \mathrm{~mm}$ nose radius tungsten carbide tool at three different feed rates (b) the SEM image of flank wear that occurred on the cutting tool at cutting speed of $35 \mathrm{~m} / \mathrm{min}$ (Magnification 100×).

Figure 6 shows the workpiece surface roughness values after the machining with $0.8 \mathrm{~mm}$ nose radius tungsten carbide tools in three different cutting speeds and feed rates. The maximum surface roughness $(0.585 \mu \mathrm{m})$ was achieved with the cutting speed of $50 \mathrm{~m} / \mathrm{min}$ and a feed rate of 0.14 $\mathrm{mm} /$ tooth, while the minimum surface roughness $(0.346 \mu \mathrm{m})$ was obtained at $20 \mathrm{~m} / \mathrm{min}$ cutting speed and $0.03 \mathrm{~mm} /$ tooth feed rate. The factors leading to a decrease/increase in the surface roughness value obtained based on the cutting speed and feed rate with the cutting tool with the radius of $0.8 \mathrm{~mm}$ are similar to the surface roughness graph obtained as a result of the machining with the cutting tool with a radius of $0.4 \mathrm{~m}$. The surface roughness (arithmetic mean values) was $0.421 \mu \mathrm{m}$ at $20 \mathrm{~m} / \mathrm{min}$, $0.463 \mu \mathrm{m}$ at $50 \mathrm{~m} / \mathrm{min}$ and $0.548 \mu \mathrm{m}$ at $35 \mathrm{~m} / \mathrm{min}$. In the chip removal process at low cutting speeds $(35 \mathrm{~m} / \mathrm{min})$, a $15 \%$ decrease $(0.463 \mu \mathrm{m})$ was observed in surface roughness with a $30 \%$ increment in the cutting speed $(50 \mathrm{~m} / \mathrm{min})$. A decrease in surface roughness was observed when the cutting speed of $35 \mathrm{~m} / \mathrm{min}$ was increased to $50 \mathrm{~m} / \mathrm{min}$. This may be attributed to easier deformation of the workpiece material and the formation of yield stress region as a result of increasing temperatures on the toolchip interface during cutting process [70-74]. $10 \%$ and $41 \%$ change was observed in surface roughness values when the feed rate was increased by $133 \%$ and $100 \%$ in the cutting process performed at 20 $\mathrm{m} / \mathrm{min}$ cutting speed and $0.7 \mathrm{~mm}$ constant cutting depth. The minimum surface roughness change was observed when the feed rate was increased from $0.03 \mathrm{~mm} /$ tooth to $0.07 \mathrm{~mm} /$ tooth (a $133 \%$ increase). The increase in surface roughness was determined as $10 \% .7 \%$ and $3 \%$ change was observed in surface roughness values when the feed rate was increased by $133 \%$ and $100 \%$ in the cutting process performed at $35 \mathrm{~m} / \mathrm{min}$ cutting speed and $0.7 \mathrm{~mm}$ constant cutting depth. The minimum surface roughness change was observed when the feed rate was increased from 0.07 $\mathrm{mm} /$ tooth to $0.14 \mathrm{~mm} /$ tooth (a 100\% increase). The increase in surface roughness was determined as $3 \%$. $9 \%$ and $39 \%$ change was observed in surface roughness values when the feed rate was increased by $133 \%$ and $100 \%$ in the cutting process performed at $50 \mathrm{~m} / \mathrm{min}$ cutting speed and $0.7 \mathrm{~mm}$ constant cutting depth. The minimum surface roughness change was observed when the feed rate was increased from $0.03 \mathrm{~mm} /$ tooth to $0.07 \mathrm{~mm} /$ tooth (a $133 \%$ increase). The increase in surface roughness was determined as $9 \%$. When the effect of cutting speed on surface roughness is examined, the lowest surface roughness was obtained at a cutting speed of $20 \mathrm{~m} / \mathrm{min}(0.421 \mu \mathrm{m})$.

The minimum surface roughness was obtained at a low feed rate $(0.03 \mathrm{~mm} /$ tooth $)(0.416 \mu \mathrm{m})$ and the maximum surface roughness was obtained at high feed rate $(0.14 \mathrm{~m} /$ tooth $)(0.565 \mu \mathrm{m})$ when the surface roughness obtained based on the feed rate was examined. When the (arithmetic) surface roughness values obtained depending on the feed rate (Figure 6) are examined, the surface roughness values obtained in the selected feed rate were found as $(0.416 \mu \mathrm{m})$ at $0.03 \mathrm{~mm} /$ tooth, $(0.451 \mu \mathrm{m})$ at $0.07 \mathrm{~mm} /$ tooth, and $(0.565 \mu \mathrm{m})$ at $0.14 \mathrm{~mm} /$ tooth, respectively from minimum to maximum. The increase in the feed rate increased the surface roughness. The increase in the amount of removed chip with the increase in the feed rate increases vibration, thereby increasing surface roughness values by accelerating the formation of wear in the cutting tool (Figure 6c) [42-45, 53, 70-72]. An improvement of $26 \%(0.416 \mu \mathrm{m})$ was observed in surface roughness $(0.565 \mu \mathrm{m})$ obtained at a high feed rate $(0.14$ $\mathrm{mm} /$ tooth $)$ with the reduction of the feed rate by $79 \%(0.03 \mathrm{~mm} /$ tooth $)$. The minimum surface roughness was obtained at a feed rate of $0.03 \mathrm{~mm} /$ tooth $(0.416 \mu \mathrm{m})$ when the feed rate effect on the surface roughness was examined. 


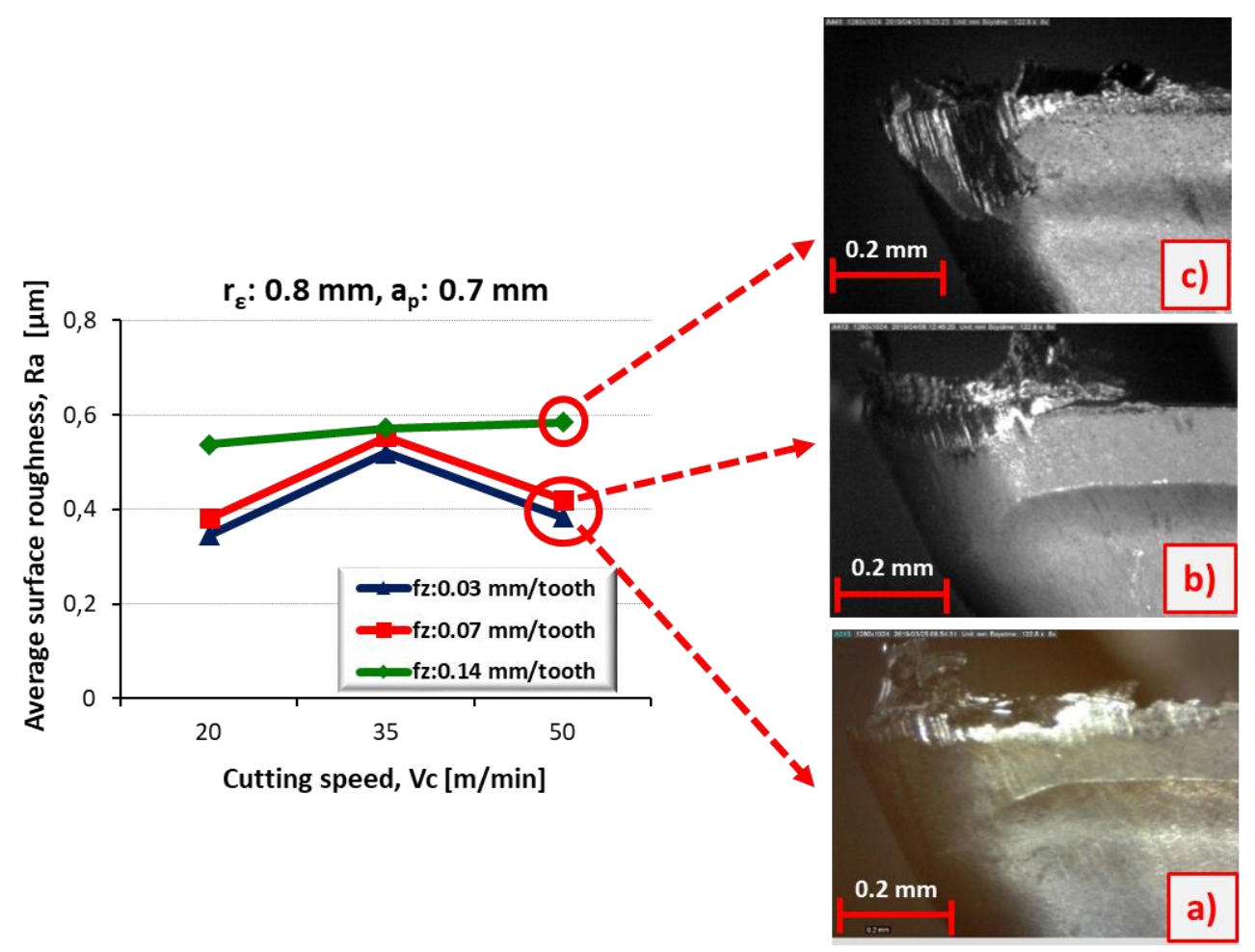

Figure 6. Surface roughness achieved by machining the NiTi shape memory alloy with $0.8 \mathrm{~mm}$ nose radius tungsten carbide tools at three different cutting speeds $(20,35$ and $50 \mathrm{~m} / \mathrm{min})$ and feed rates $(0.03,0.07$ and $0.14 \mathrm{~mm} /$ tooth $)$, and the tool wear images at high cutting speed (50 m/min) with a) $0.3 \mathrm{~mm} /$ tooth, b) 0.07 $\mathrm{mm} /$ tooth, and c) $0.14 \mathrm{~mm} /$ tooth.

The workpiece surface roughness values obtained as a result of the machining of NiTi shape memory alloys with two different nose radii $(0.4 \mathrm{~mm}$ and $0.8 \mathrm{~mm})$ at three different cutting speeds and feed rates are graphically given in Figure 7 and Figure 8. Based on the cutting speed and feed rates in Figure 7 and 8, the maximum surface roughness was achieved with the cutting tool with a nose radius of $0.4 \mathrm{~mm}$ at cutting speed of $50 \mathrm{~m} / \mathrm{min}$ and a feed rate of $0.14 \mathrm{~mm} /$ tooth $(0.736 \mu \mathrm{m})$, while the minimum surface roughness was achieved with the cutting tool of $0.8 \mathrm{~mm}$ nose radius at a cutting speed of $20 \mathrm{~m} / \mathrm{min}$ and a feed rate of $0.03 \mathrm{~mm} /$ tooth $(0.346 \mu \mathrm{m})$. The surface roughness achieved with a $0.4 \mathrm{~mm}$ nose radius cutting tool was $0.530 \mu \mathrm{m}$ at $20 \mathrm{~m} / \mathrm{min}, 0.632 \mu \mathrm{m}$ at $50 \mathrm{~m} / \mathrm{min}$, and $0.660 \mu \mathrm{m}$ at $35 \mathrm{~m} / \mathrm{min}$. For the nose radius of $0.8 \mathrm{~mm}$, surface roughness decreased to $0.421 \mu \mathrm{m}$ at $20 \mathrm{~m} / \mathrm{min}, 0.463$ $\mu \mathrm{m}$ at $50 \mathrm{~m} / \mathrm{min}$, and $0.548 \mathrm{~mm}$ at $35 \mathrm{~m} / \mathrm{min}$. These results revealed that surface roughness decreases as the nose radius of the cutting tool increases. This result is consistent with those in the literature [38-45, 50-53]. 

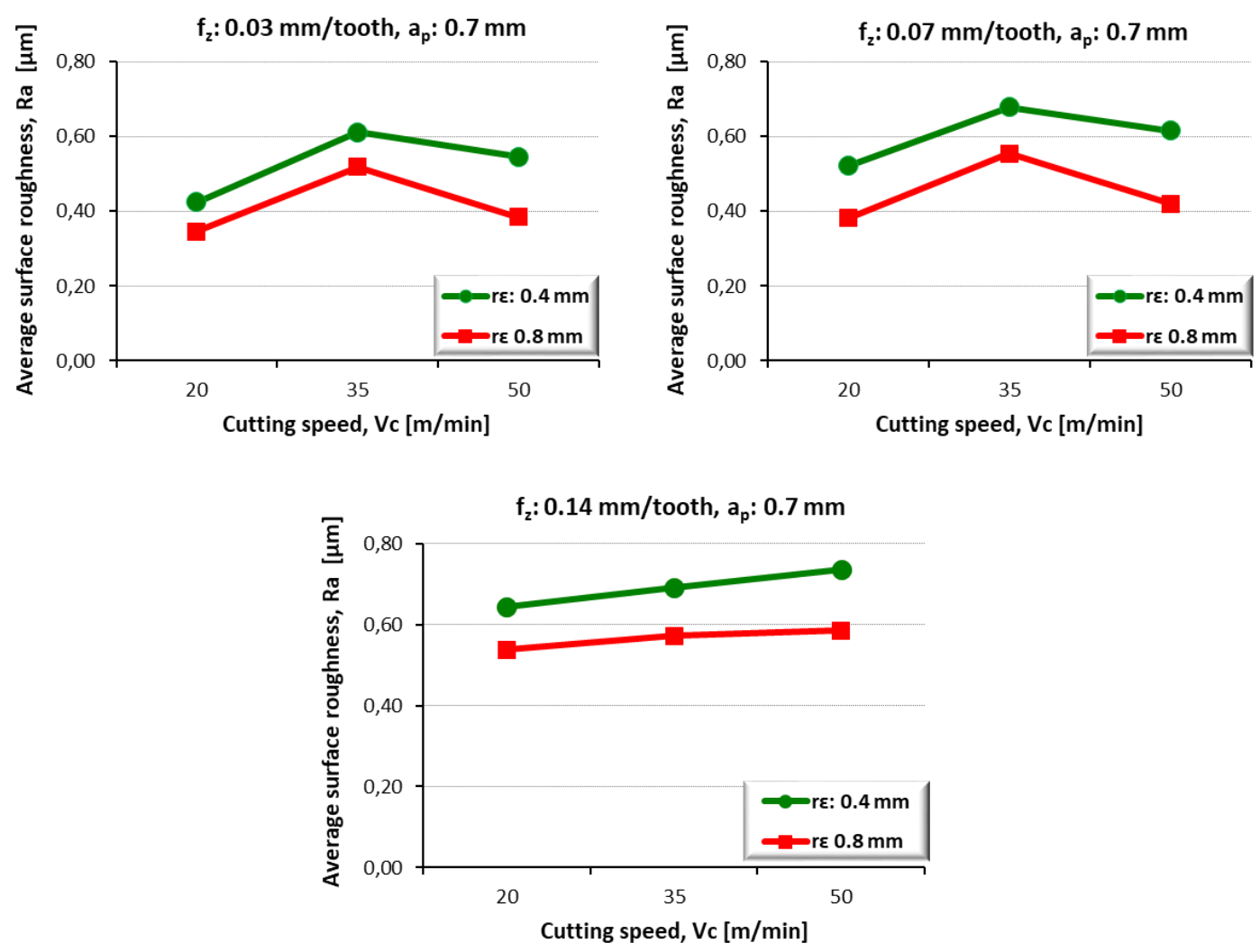

Figure 7. The surface roughness change diagrams of NiTi shape memory alloy with tungsten carbide tools at two different nose radii $(0.4 \mathrm{~mm}$ and $0.8 \mathrm{~mm})$ and three different cutting speeds $(20,35$, and $50 \mathrm{~m} / \mathrm{min})$.

When surface roughness obtained depending on the feed rate was examined (Figure 8), it was found that surface roughness achieved with a $0.4 \mathrm{~mm}$ nose radius cutting tool was $0.527 \mu \mathrm{m}$ at 0.03 $\mathrm{mm} /$ tooth, $0.605 \mu \mathrm{m}$ at $0.07 \mathrm{~mm} /$ tooth and $0.691 \mu \mathrm{m}$ at $0.14 \mathrm{~mm} /$ tooth. When the nose radius was chosen as $0.8 \mathrm{~mm}$, the change in obtained surface roughness was $0.416 \mu \mathrm{m}$ at $0.03 \mathrm{~mm} /$ tooth, 0.451 $\mu \mathrm{m}$ at $0.07 \mathrm{~mm} /$ tooth, and $0.565 \mu \mathrm{m}$ at $0.014 \mathrm{~mm} /$ tooth from lowest to highest. When the effect of feed rates on surface roughness was examined, it was found that the lowest surface roughness was achieved with $0.8 \mathrm{~mm}$ nose radius cutting tools at $0.03 \mathrm{~mm} /$ tooth feed rate, and a $21 \%$ decrease was observed $(0.416 \mu \mathrm{m})$. It was determined that the surface roughness value increased as the feed rate of both cutting tools increased. These findings coincide with those in the literature [24, 42, 70-74]. The decrease in surface roughness depending on the increase in the nose radius is an expected result theoretically (Equation 1) and increasing the nose radius to obtain lower surface roughness value is in line with the literature [38-45, 52-55, 70-72]. Maximum surface roughness was obtained with 0.4 $\mathrm{mm}$ nose radius cutting tools, while the minimum surface roughness was obtained with tools with a nose radius of $0.8 \mathrm{~mm}$. 

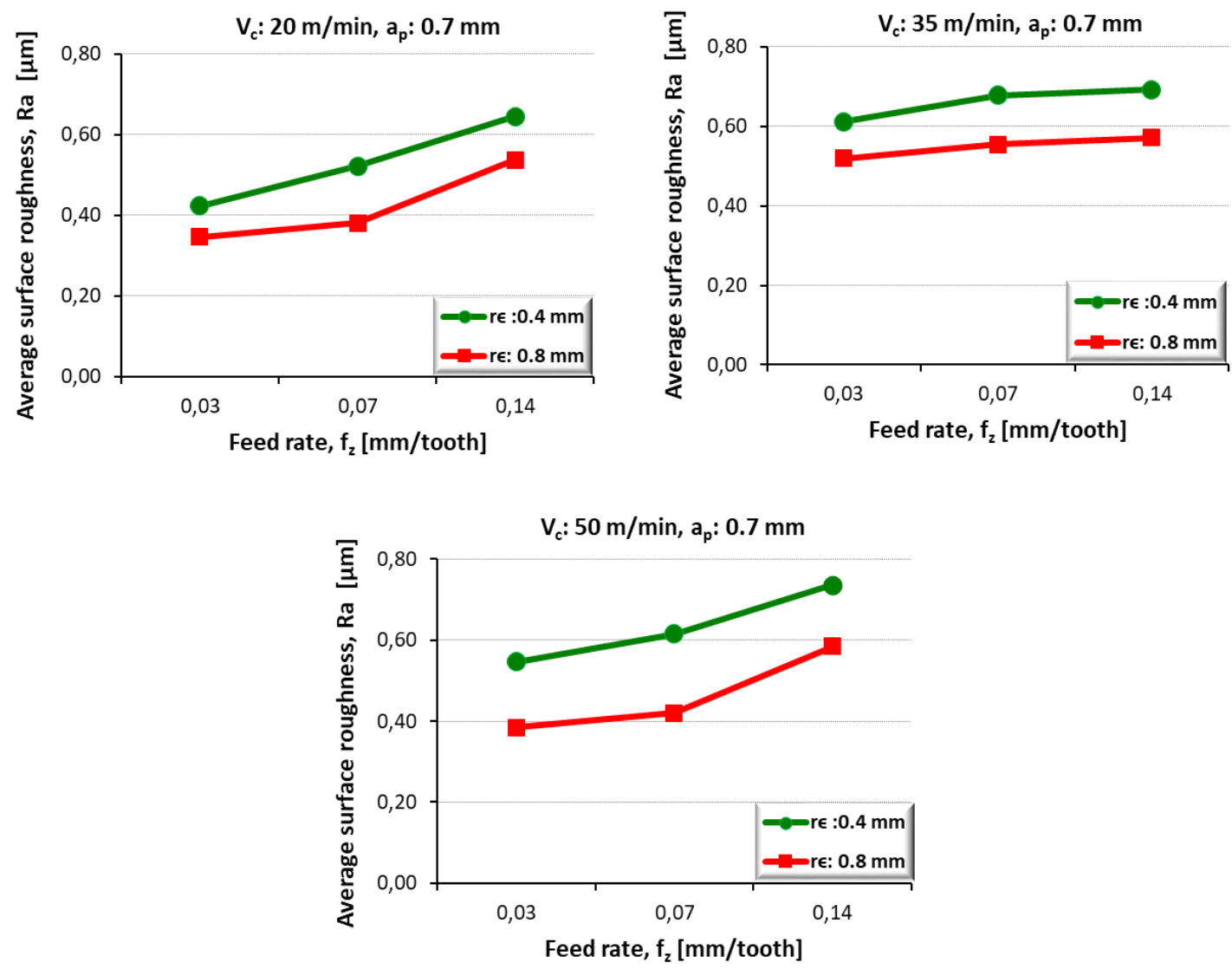

Figure 8. The surface roughness change diagrams $(\mathrm{Ra})$ of NiTi shape memory alloy with tungsten carbide tools at two different nose radii $(0.4 \mathrm{~mm}$ and $0.8 \mathrm{~mm})$ and three different feed rates $(0.03,0.07$ and 0.14 $\mathrm{mm} /$ tooth).

\subsection{Change in Tool Life Based on Cutting Speed and Feed Rate}

The wear of cutting tools after machining the NiTi shape memory alloy with $0.4 \mathrm{~mm}$ nose radius tungsten carbide tools at three different cutting speeds and feed rates are shown by the OM images in Figure 9. It is evident from the OM images that the high deformation hardening property of NiTi shape memory alloy caused abrasive wear, while the ductility of this alloy caused adhesive wear. The wear mechanisms that occurred are as follows: flank wear, built-up edge (BUE), mechanical fatigue fracture, fracture wear and crater wear. The lifetime of cutting tools depends mostly on the flank wear caused by abrasion (Figure 10). We observed that the wear of the flank wear surface increases if the cutting speed and feed rate increase. The flank wear value obtained after the chip removal process performed at three different cutting speeds $(20,35$ and $50 \mathrm{~m} / \mathrm{min})$ and low feed value $(0.03 \mathrm{~mm} /$ tooth $)$ was low $(0.584 \mathrm{~mm})$, while it increased up to $0.887 \mathrm{~mm}$ when the feed rate increased up to $0.14 \mathrm{~mm} /$ tooth (see Figure 9). A BUE formation was observed on the tool-chip interface at low cutting speed (20 m/min) (Figure 9a). At high cutting speed (50 m/min), BUE formation decreased. However, a high incidence of flank wear formation occurred in proportion to the low cutting speeds (Figure 91). It was observed that a lower flank wear formation occurred at low cutting speed (20 $\mathrm{m} / \mathrm{min}$.) in comparison to the one that occurred at high cutting speed (Figure $9 \mathrm{~b}$ ). 


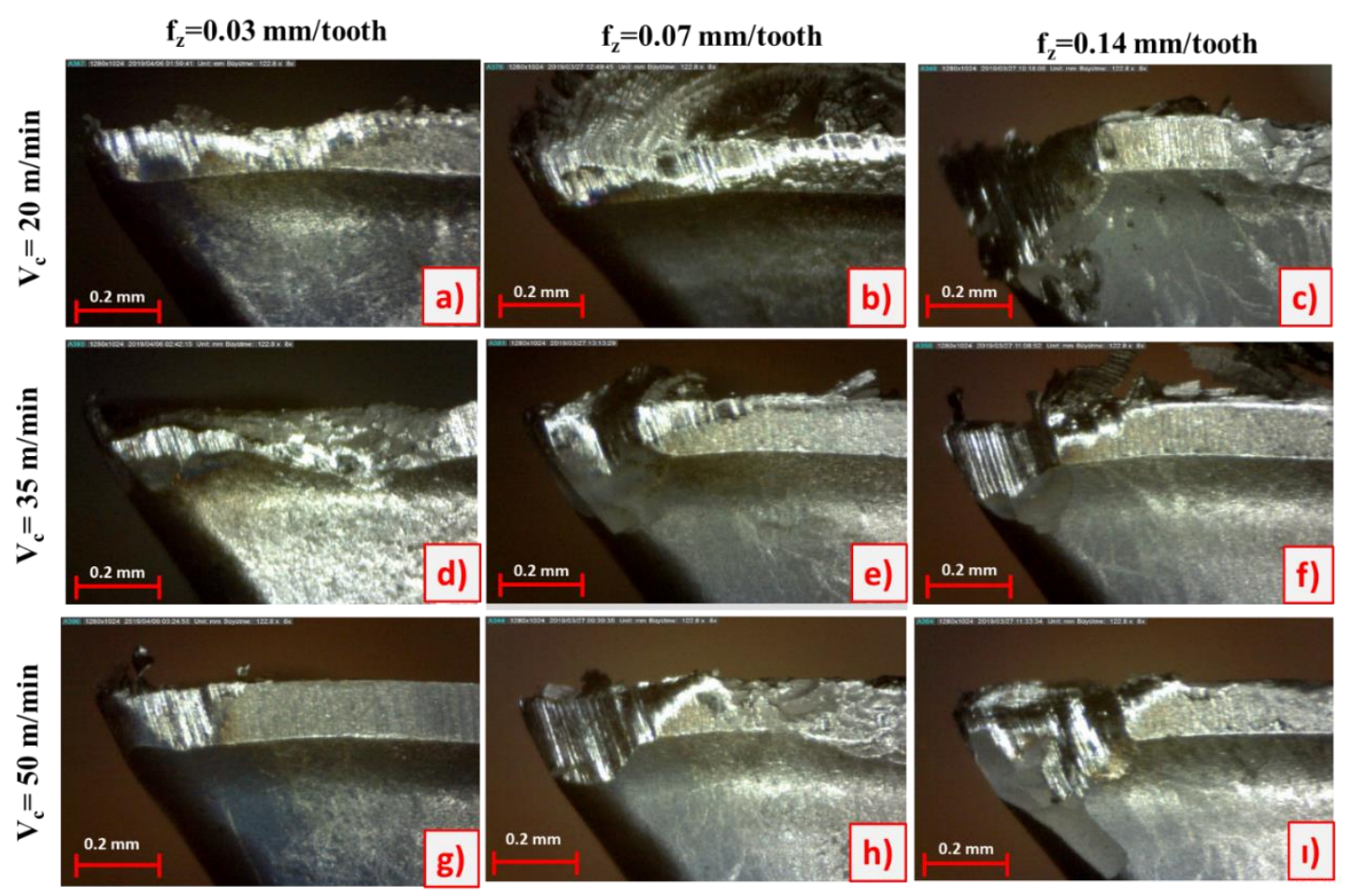

Figure 9. The tool wear after cutting the NiTi shape memory alloy with $0.4 \mathrm{~mm}$ nose radius tungsten carbide tools at three different cutting speeds $(20,35$ and $50 \mathrm{~m} / \mathrm{min})$ and feed rates $(0.03,0.07$ and 0.14 $\mathrm{mm} /$ tooth).

The SEM images of the tool wears that occurred on the cutting tools as a result of machining the NiTi shape memory alloy with $0.4 \mathrm{~mm}$ nose radius tungsten carbide tools at three different cutting speeds and feed rates are shown in Figure 10. As it is evident from the SEM images, flank wear increased as the cutting speed and feed rate increased. The wear type in the cutting tool at the cutting speed of $35 \mathrm{~m} / \mathrm{min}$ and the feed value of $0.03 \mathrm{~mm} /$ tooth was identified as mechanical fatigue fracture (Figure 10d). This form of wear could be due to the low strength of cutting edge, the mechanical fatigue and high temperature [72]. BUE was observed at a cutting speed of $35 \mathrm{~m} / \mathrm{min}$ due to the low temperature at the tool-chip interface (Figure 10b). The wear types of cutting edge at high cutting speed $(50 \mathrm{~m} / \mathrm{min})$ and feed rate $(0.14 \mathrm{~mm} /$ tooth) were identified as BUE and fracture tool wear (Figure 10). We assume that the fracture tool wear was caused by the mechanical and thermal fatigue that occurred because of discontinuous cutting (such as milling) [32, 43, 69-74]. 

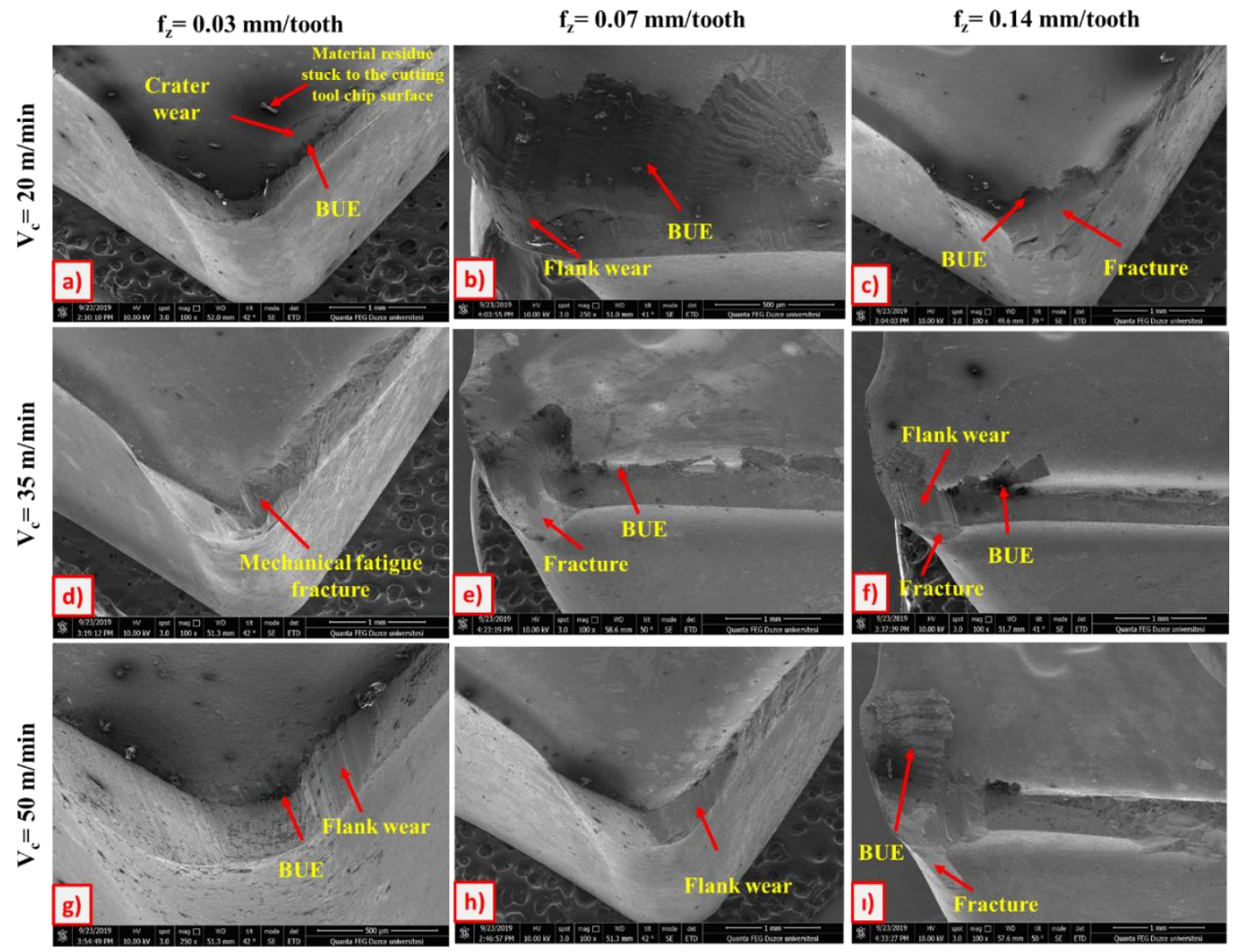

Figure 10. The SEM images of tool wear that formed with the cutting of the NiTi shape memory alloy with tungsten carbide tools ( $0.4 \mathrm{~mm}$ nose radius) at three different cutting speeds $(20,35$ and $50 \mathrm{~m} / \mathrm{min})$ and feed rates $(0.03,0.07$ and $0.14 \mathrm{~mm} /$ tooth) (Magnification 100×).

The SEM images and the EDX analysis images of tool wear (Figure 10e) that formed during milling at a cutting speed of $35 \mathrm{~m} / \mathrm{min}$ and feed rate of $0.07 \mathrm{~mm} /$ tooth are shown in Figure 11. The SEM images in Figure 11 show that abrasive and adhesive wear have an effect on BUE, and cutting edge fracture occurred. The Image of elemental analysis (EDX) performed over the fracture wear is shown in Figure 11d. When the EDX analysis results were examined, adhesion of the workpiece material to the carbide base and the oxidation of W (Wolfram) in the carbide base were determined. The fracture on the cutting edge (Figure 11c) is due to the decrease in strength due to high temperature and high cutting forces [38, 42, 69-71]. 


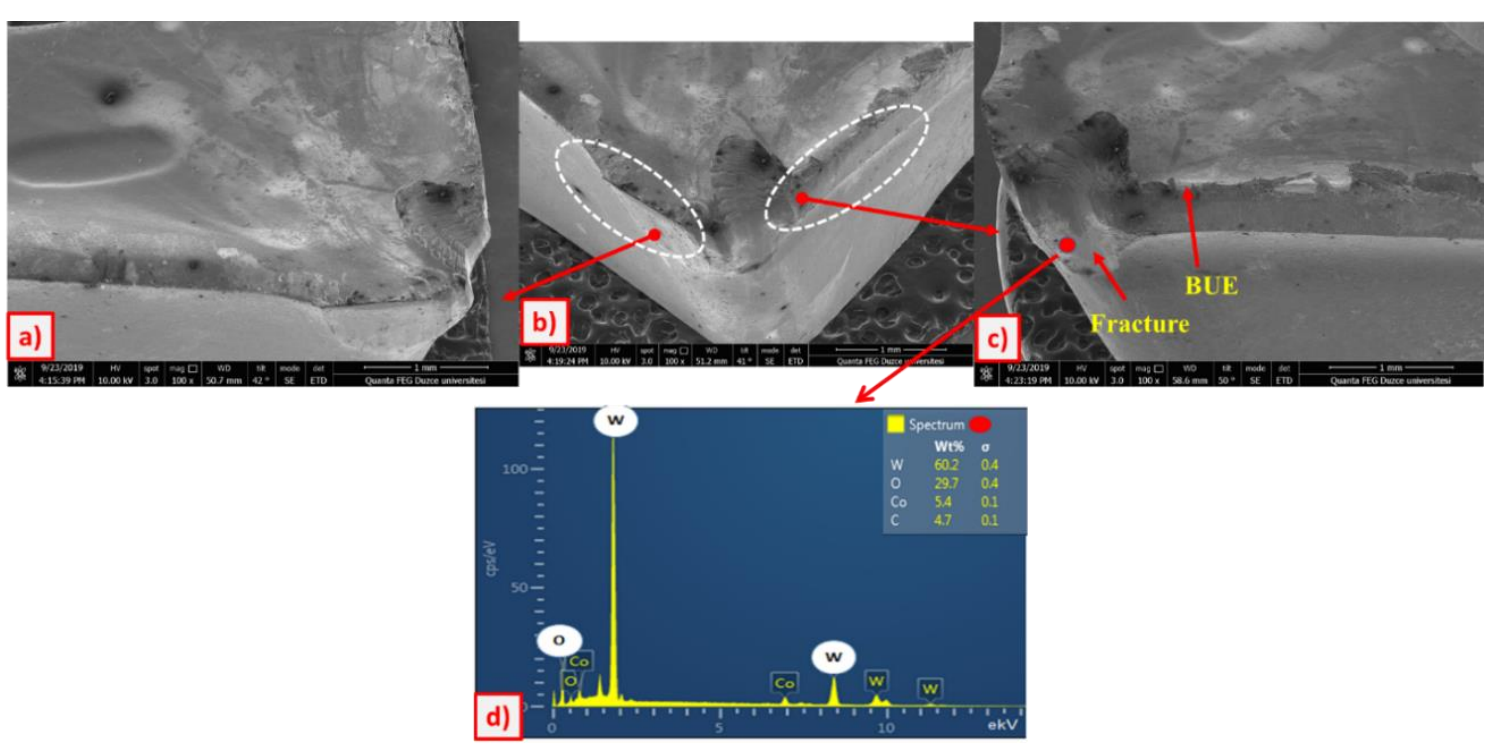

Figure 11. The SEM images and EDX analysis values of cutting edge wear during the machining of the NiTi shape memory alloy with a $0.4 \mathrm{~mm}$ nose radius tungsten carbide tools at a cutting speed of $35 \mathrm{~m} / \mathrm{min}$ and feed rate of $0.07 \mathrm{~mm} /$ tooth (Magnification 100×).

Figure 12 shows the values of flank wear that occurred on the cutting tools during the machining of NiTi shape memory alloy with $0.4 \mathrm{~mm}$ nose radius tungsten carbide tools at three different cutting speeds and feed rates. The maximum flank wear (0.942) was obtained at a cutting speed of $50 \mathrm{~m} / \mathrm{min}$ and a feed rate of $0.14 \mathrm{~mm} /$ tooth, while the minimum flank wear $(0.435 \mathrm{~mm})$ occurred at a cutting speed of $20 \mathrm{~m} / \mathrm{min}$ and a feed rate of $0.03 \mathrm{~mm} /$ tooth (see Figure 12). The flank wear values obtained depending on cutting speed were $0.627 \mathrm{~mm}$ at $20 \mathrm{~m} / \mathrm{min}$ ), $0.758 \mathrm{~mm}$ at $50 \mathrm{~m} / \mathrm{min}$, and $0.813 \mathrm{~mm}$ at 35 $\mathrm{m} / \mathrm{min}$. A $7 \%$ decrease $(0.758 \mathrm{~mm})$ was observed in flank wear when the cutting speed was increased by $30 \%$ (50 $\mathrm{m} / \mathrm{min}$ ) during the chip removal process at low cutting speeds $(35 \mathrm{~m} / \mathrm{min})$. This may be attributed to the increase in the temperature of the tool-chip interface with the increase in the cutting speed, and accordingly, to the workpiece softening and the ability of the cutting tools to keep their hardness at high temperatures [43-45, 70-74]. The increased temperature on the tool-chip interface at high cutting speed $(50 \mathrm{~m} / \mathrm{min}$ ) also causes thermal softening of the cutting tool. However, the softening of the workpiece material at high cutting speed $(50 \mathrm{~m} / \mathrm{min})$ is higher than the thermal softening of the cutting tool. Therefore, the flank wear of the cutting tool decreased [42-45, 53, 71-74]. A $48 \%$ and a $25 \%$ change were observed in the flank wear value as the feed rate increased by $133 \%$ and $100 \%$ in the cutting process performed at $20 \mathrm{~m} / \mathrm{min}$. cutting speed and $0.7 \mathrm{~mm}$ constant depth of cut. The minimum flank wear change was seen when the feed rate of $0.07 \mathrm{~mm} /$ tooth was increased to $0.14 \mathrm{~mm} /$ tooth (a $100 \%$ increase). A $5 \%$ and a $38 \%$ change were observed in flank wear as the feed rate increased by $133 \%$ and $100 \%$ in the cutting process performed at $50 \mathrm{~m} / \mathrm{min}$. cutting speed and $0.7 \mathrm{~mm}$ constant depth of cut. The minimum flank wear change was seen when the feed rate of 0.03 $\mathrm{mm} /$ tooth was increased to $0.07 \mathrm{~mm} /$ tooth (a $133 \%$ increase). When the effect of cutting speed on flank wear was examined, the minimum flank wear was achieved at $20 \mathrm{~m} / \mathrm{min}$ cutting speed $(0.627$ $\mathrm{mm})$.

The maximum flank wear $(0.887 \mathrm{~mm})$ was obtained at high feed rate $(0.14 \mathrm{~mm} /$ tooth $)$ and the minimum value $(0.584 \mathrm{~mm})$ was obtained at low feed rate $(0.03 \mathrm{~mm} /$ tooth $)$. The flank wear values 
obtained depending on the feed rate were attained as $(0.584 \mathrm{~mm})$ at $0.03 \mathrm{~mm} /$ tooth,$(0.727 \mathrm{~mm})$ at $0.07 \mathrm{~mm} /$ tooth, and $(0.887 \mathrm{~mm})$ at $0.14 \mathrm{~mm} /$ tooth, respectively from minimum to maximum. A $34 \%$ improvement $(0.584 \mathrm{~mm})$ was achieved in flank wear obtained at a high feed rate $(0.14 \mathrm{~mm} /$ tooth $)$ $(0.887 \mathrm{~mm})$ as the feed rate was decreased by $79 \%(0.03 \mathrm{~mm} /$ tooth $)$. As the feed rate increases, the amount of heat generated in environment also increases. Since NiTi shape memory alloys have lower thermal conductivity, heat could not be removed and flank wear increased due to the effect of high temperature and pressure (see Figure 12) [40-45, 71-74]. The minimum flank wear $(0.584 \mathrm{~mm})$ was achieved at a feed rate of $0.03 \mathrm{~mm} /$ tooth.

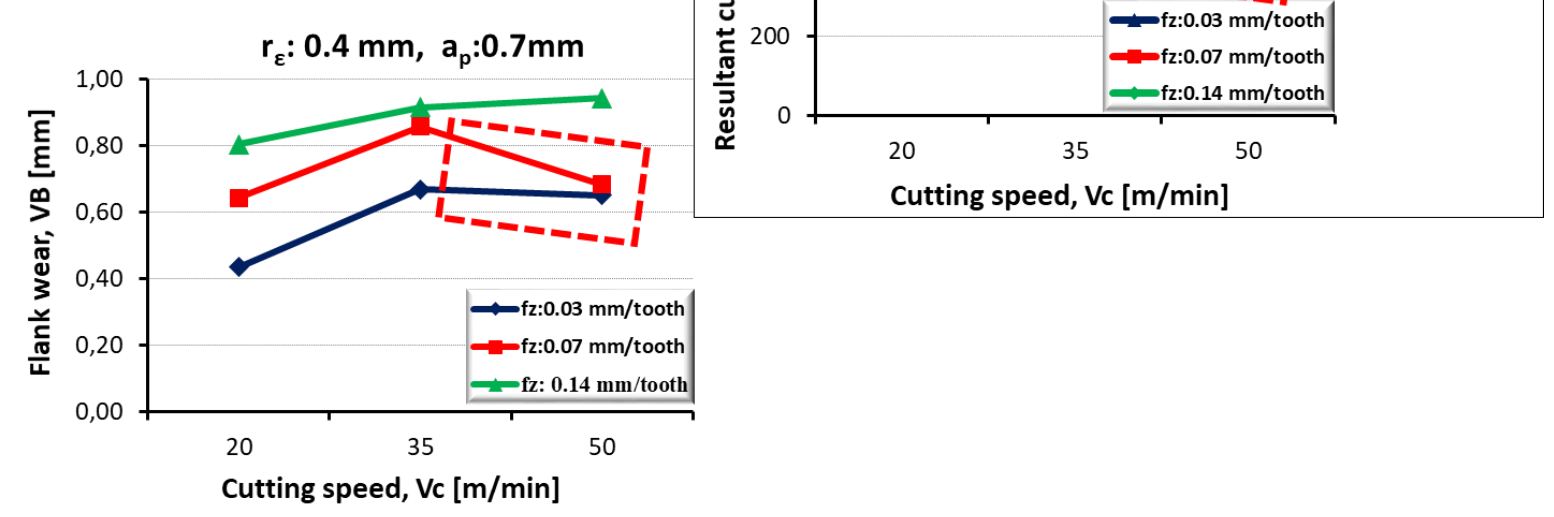

Figure 12. Flank wear of cutting tool during the machining of the NiTi shape memory alloy with a $0.4 \mathrm{~mm}$ nose radius tungsten carbide tools at three different cutting speeds $(20,35$ and $50 \mathrm{~m} / \mathrm{min})$ and feed rates (0.03, 0.07 and $0.14 \mathrm{~mm} /$ tooth).

Figure 13 shows the OM images of the cutting tool edge after the machining of NiTi shape memory alloy with $0.8 \mathrm{~mm}$ nose radius tungsten carbide tools at three different cutting speeds and feed rates. Different types of wear can be observed on these images (BUE, flank wear, mechanical fatigue fracture, crater wear and fracture wear). As we have already mentioned, flank wear resulted from abrasive wear. As both cutting speed and feed rate increase, flank wear also increase. The increase in cutting speed and feed rate led to an increase in the cutting temperature of cutting edge. At elevated temperature, a chemical reaction occurred between the carbide cutting tool and the workpiece material. Therefore, with increased temperature, flank wear on the cutting tool increases [38-45, 68-72]. Thus the highest flank wear value $(0.796 \mathrm{~mm})$ was observed at low cutting speed (50 $\mathrm{m} / \mathrm{min}$.) and feed rate $(0.14 \mathrm{~mm} /$ tooth) (Figure 13i). Low flank wear value at low cutting speed (20 $\mathrm{m} / \mathrm{min})$ and low feed rate $(0.03 \mathrm{~mm} /$ tooth) caused the formation of BUE on the cutting tool (Figure 13a). This can be explained by the low temperature that formed at the tool-chip interface [70-74]. 


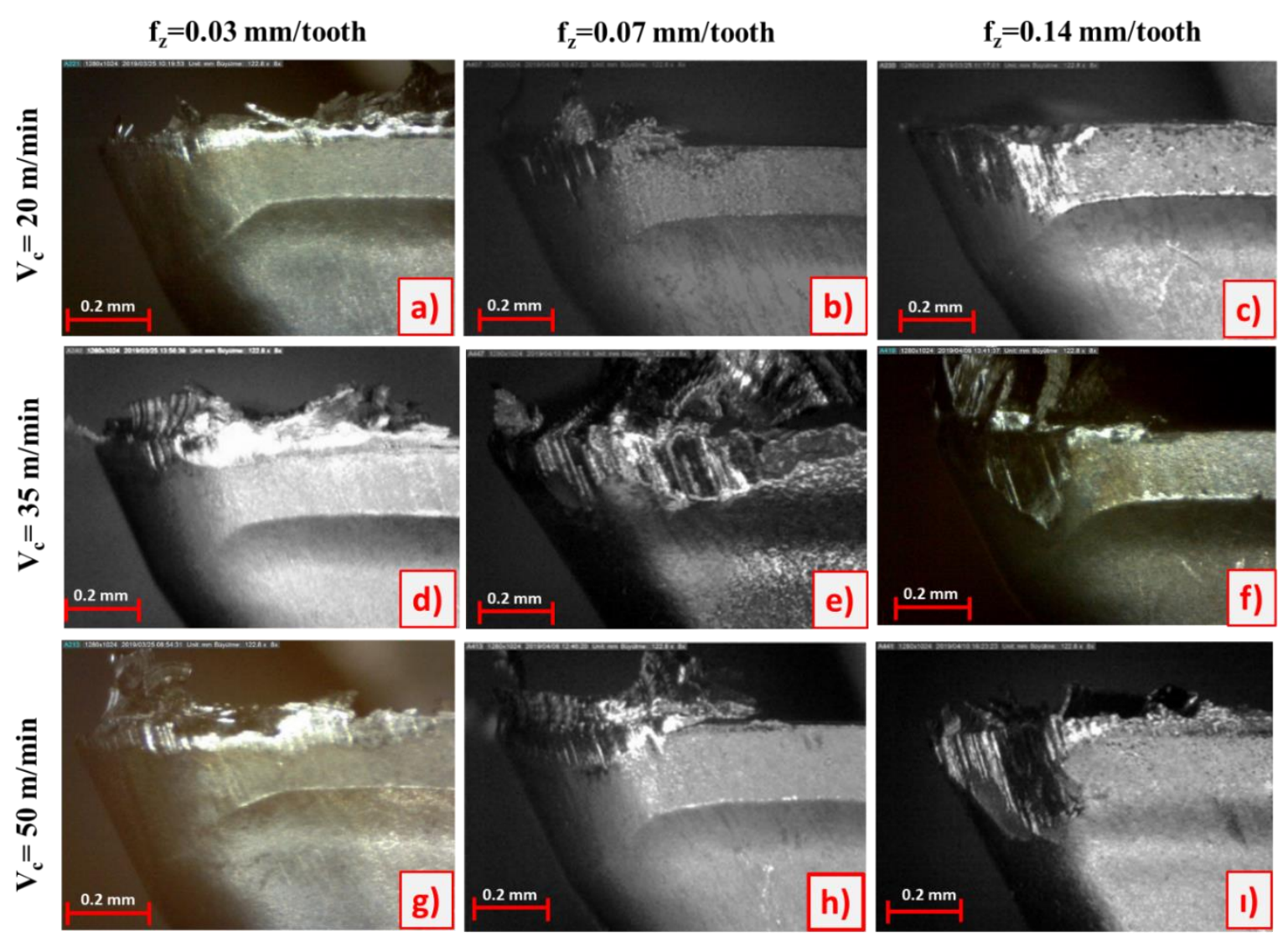

Figure 13. The OM images of cutting edge after the machining of the NiTi shape memory alloy with a 0.8 $\mathrm{mm}$ nose radius tungsten carbide tools at three different cutting speeds $(20,35$ and $50 \mathrm{~m} / \mathrm{min}$ ) and feed rates $(0.03,0.07$ and $0.14 \mathrm{~mm} /$ tooth) (Magnification $100 \times)$.

Figure 14 shows the SEM images of the cutting edge after the machining of NiTi shape memory alloy with $0.8 \mathrm{~mm}$ nose radius tungsten carbide tools at three different cutting speeds and feed rates. The reason for the formation of BUE on the cutting tool is the chemical structure of the workpiece with the low temperature caused by friction between the cutting tool and the workpiece, especially at low cutting speeds. The parts are cut off from the cutting tool with the breaking of the BUEs that formed on the cutting tool and hardened in time. Therefore, breaks occur in the tool by means of the adhesion mechanism [42-48, 53, 70-73]. The SEM image in Figure 14f shows what happens when the cutting speed is $50 \mathrm{~m} / \mathrm{min}$ and the feed rate is $0.03 \mathrm{~mm} /$ tooth. On these images, two different types of wear can be identified: mechanical fatigue fracture and crater wear. The crater wear on the rake face wear is due to the elevated temperature resulting from high cutting speed [40-43, 72]. When the cutting speed is $50 \mathrm{~m} / \mathrm{min}$ and the feed rate is $0.14 \mathrm{~mm} /$ tooth, the predominant wears are BUE, flank wear and the fracture in cutting edge (see Figure 14i). The damage in the cutting edge resulting from fracture is due to cyclical loads (thermal and mechanical shocks) on the cutting edge in the cutting process. [69-74]. 


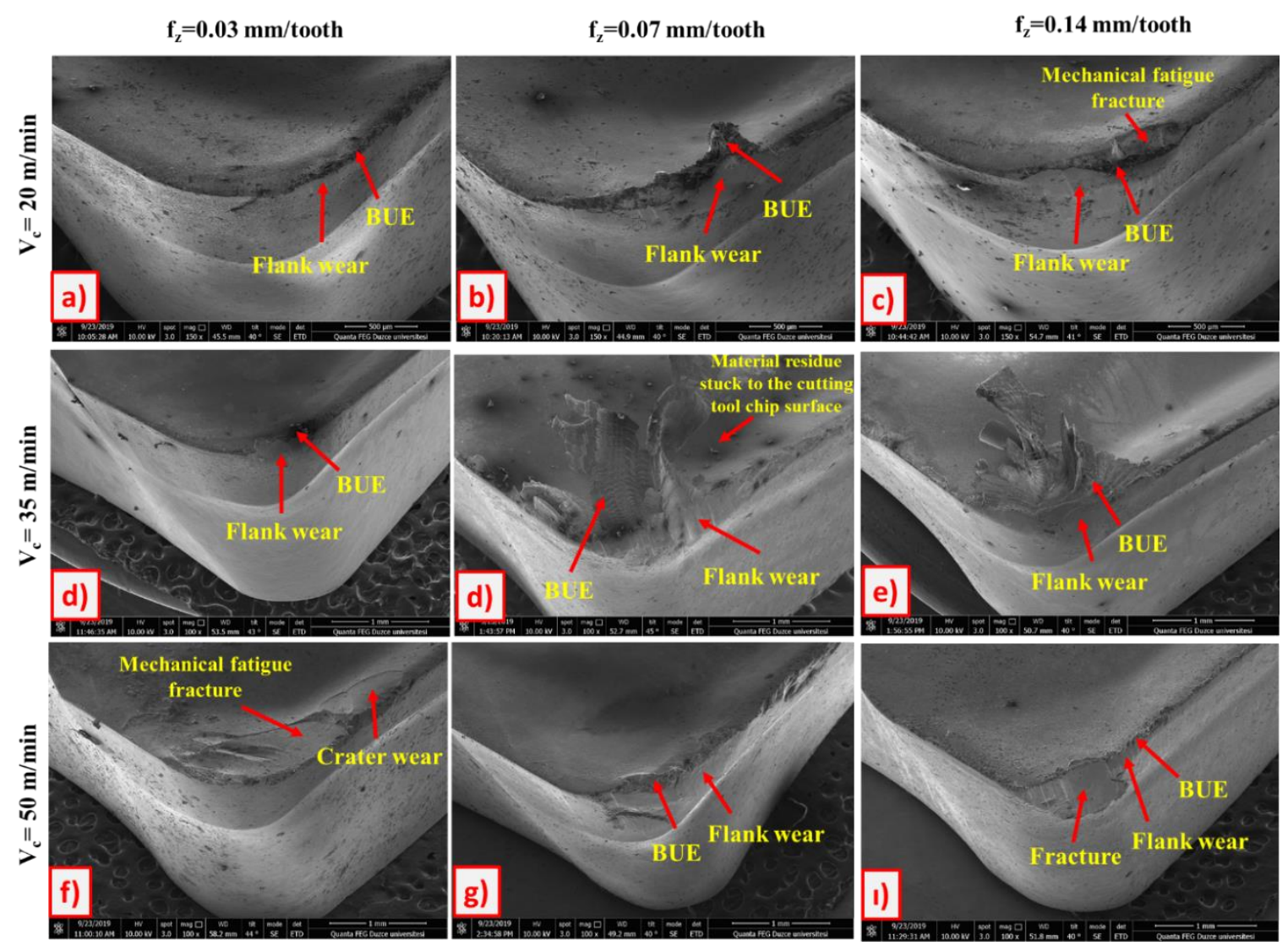

Figure 14. The SEM images of the cutting edge after the machining of NiTi shape memory alloy with 0.8 $\mathrm{mm}$ nose radius tungsten carbide tools at three different cutting speeds $(20,35$ and $50 \mathrm{~m} / \mathrm{min})$ and feed rates $(0.03,0.07$ and $0.14 \mathrm{~mm} /$ tooth) (Magnification $100 \times)$.

Figure 14e shows the SEM images and EDX analysis of cutting edge after milling at the cutting speed of $35 \mathrm{~m} / \mathrm{min}$ and the feed rate of $0.07 \mathrm{~mm} /$ tooth. It is evident that the dominant wears were flank wear and BUE. It is thought that the flank wear resulting from the abrasive wear mechanism was caused by the hard carbide particles in the workpiece material [65-67, 69.70]. BUE formation has been attributed to low temperature formation on tool-chip interface during the machining of the NiTi shape memory alloy [38-43, 69-73]. An elemental analysis of BUE was performed with EDX and its image is shown in Figure 15d. The EDX analysis results show that carbide base material and chips were oxidized. 


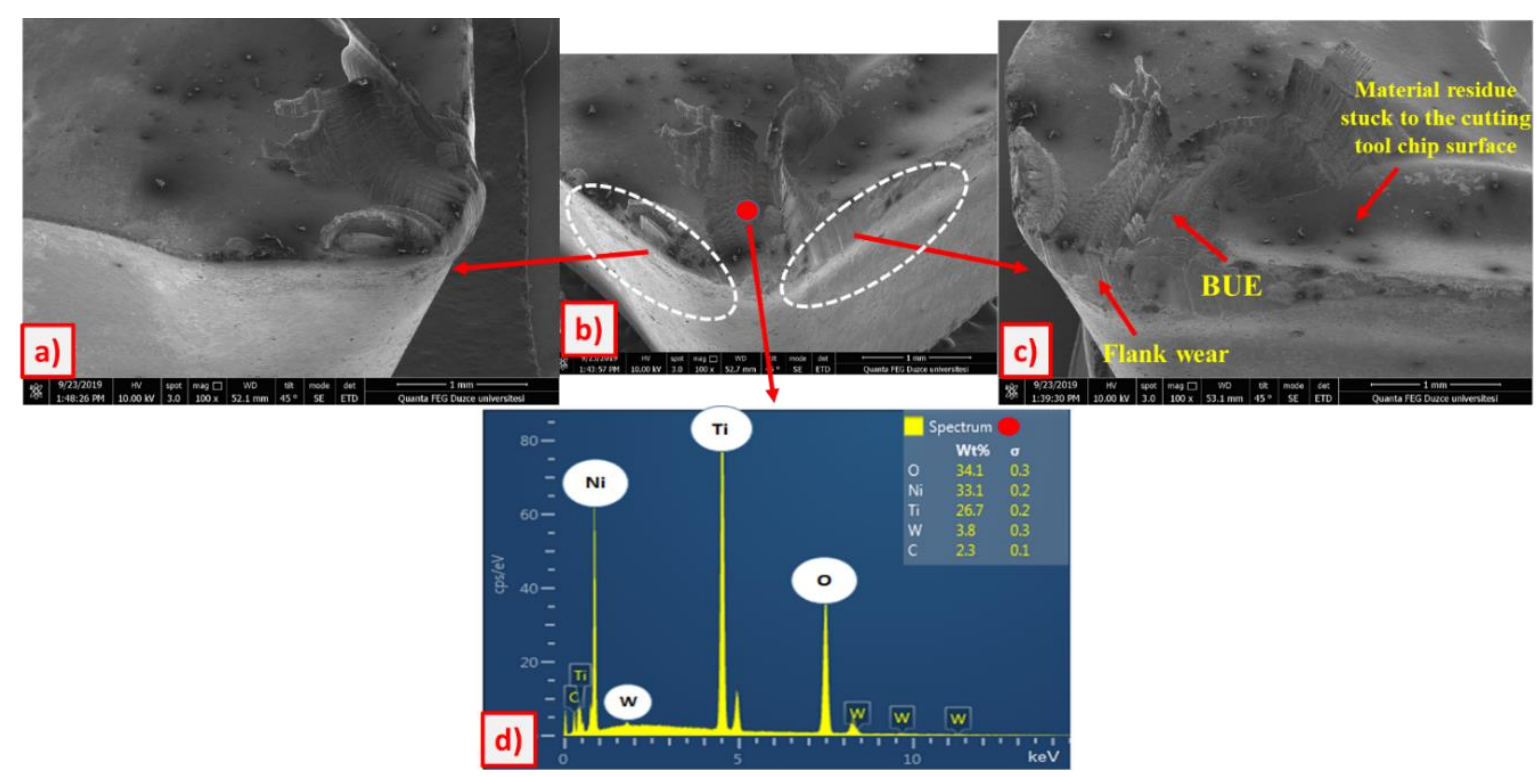

Figure 15. The SEM images of the cutting edge after the machining of the NiTi shape memory alloy with $0.8 \mathrm{~mm}$ nose radius tungsten carbide tools at three different cutting speeds $(20,35$ and $50 \mathrm{~m} / \mathrm{min})$ and feed rates $(0.03,0.07$ and $0.14 \mathrm{~mm} /$ tooth) (Magnification $100 \times)$.

The flank wear of the cutting tools during the machining of the NiTi shape memory alloy with $0.8 \mathrm{~mm}$ nose radius tungsten carbide tools at three different cutting speeds and feed rates is shown in Figure 16. The maximum flank wear $(0.796 \mathrm{~mm})$ was obtained at the cutting speed of $50 \mathrm{~m} / \mathrm{min}$ and the feed rate of $0.14 \mathrm{~mm} /$ tooth, while the minimum flank wear was achieved at the cutting speed of $20 \mathrm{~m} / \mathrm{min}$ and the feed rate of $0.03 \mathrm{~mm} /$ tooth $(0.264 \mathrm{~mm})$. The reasons for the flank wear changes are the same as those we described for tungsten carbide tools with $0.4 \mathrm{~mm}$ nose. When flank wear based on the feed rate is examined, the obtained flank wear values were found as $(0.415 \mathrm{~mm})$ at 20 $\mathrm{m} / \mathrm{min}),(0.514 \mathrm{~mm})$ at $50 \mathrm{~m} / \mathrm{min}$, and $(0.597 \mathrm{~mm})$ at $35 \mathrm{~m} / \mathrm{min}$ respectively from minimum to maximum. A $14 \%$ decrease $(0.514 \mathrm{~mm})$ was observed in flank wear with a $30 \%$ increase in cutting speed $(50 \mathrm{~m} / \mathrm{min}$ ) in the chip removal process at low cutting speeds $(35 \mathrm{~m} / \mathrm{min})$. A $10 \%$ and a $41 \%$ change were observed in the value of flank wear when the feed rate was increased by $133 \%$ and $100 \%$ in the cutting process performed at $20 \mathrm{~m} / \mathrm{min}$ cutting speed and $0.7 \mathrm{~mm}$ constant depth of cut. The minimum flank wear change was seen when the feed rate was increased from $0.03 \mathrm{~mm} /$ tooth to $0.07 \mathrm{~mm} /$ tooth (a $133 \%$ increase). A $7 \%$ and a $3 \%$ change were observed in the value of flank wear when the feed rate was increased by $133 \%$ and $100 \%$ in the cutting process performed at $35 \mathrm{~m} / \mathrm{min}$ cutting speed and $0.7 \mathrm{~mm}$ constant depth of cut. The minimum flank wear was observed when the feed rate was increased from $0.07 \mathrm{~mm} /$ tooth to $0.14 \mathrm{~mm} /$ tooth (a $100 \%$ increase). A $9 \%$ and a $39 \%$ change were observed in the value of flank wear when the feed rate was increased by $133 \%$ and $100 \%$ in the cutting process performed at $50 \mathrm{~m} / \mathrm{min}$ cutting speed and $0.7 \mathrm{~mm}$ constant depth of cut. The minimum flank wear change was seen when the feed rate was increased from $0.03 \mathrm{~mm} /$ tooth to 0.07 $\mathrm{mm} /$ tooth (a 133\% increase). When the effect of the cutting speed on flank wear was examined, the minimum flank wear was achieved at $20 \mathrm{~m} / \mathrm{min}$ cutting speed $(0.415 \mathrm{~mm})$. 
When flank wear based on the feed rate is examined, it was seen that the maximum flank wear $(0.744 \mathrm{~mm})$ was obtained at high feed rate of $0.14 \mathrm{~mm} /$ tooth, while the minimum flank wear $(0.300$ $\mathrm{mm}$ ) was obtained at low feed rate of $0.03 \mathrm{~mm} /$ tooth. The flank wear values obtained based on feed rate were $(0.300 \mathrm{~mm})$ at the lowest feed rate of $0.03 \mathrm{~mm} /$ tooth, $(0.482 \mathrm{~mm})$ at the feed rate of 0.07 $\mathrm{mm} /$ tooth, and $(0.744 \mathrm{~mm})$ at the feed rate of $0.14 \mathrm{~mm} /$ tooth, respectively from minimum to maximum. An increase in flank wear was observed due to the feed rate [68-74]. This situation causes an increase in the surface roughness of the workpiece (Figure 6). A 60\% improvement $(0.300 \mathrm{~mm})$ was observed in flank wear obtained at a high feed rate $(0.14 \mathrm{~mm} /$ tooth $)(0.744 \mathrm{~mm})$ when the feed rate was decreased by $79 \%$. An increase in flank wear was detected at three different cutting speeds $(20,35$ and $50 \mathrm{~m} / \mathrm{min})$ and high feed rate $(0.14 \mathrm{~mm} /$ tooth $)$ as it can be seen in the graph in Figure 16 (Figure 13c, Figure 13f, Figure 13i). It has been determined that worn cutting tools caused poor quality in the machined surface and accordingly an increase in surface roughness (Figure 6).

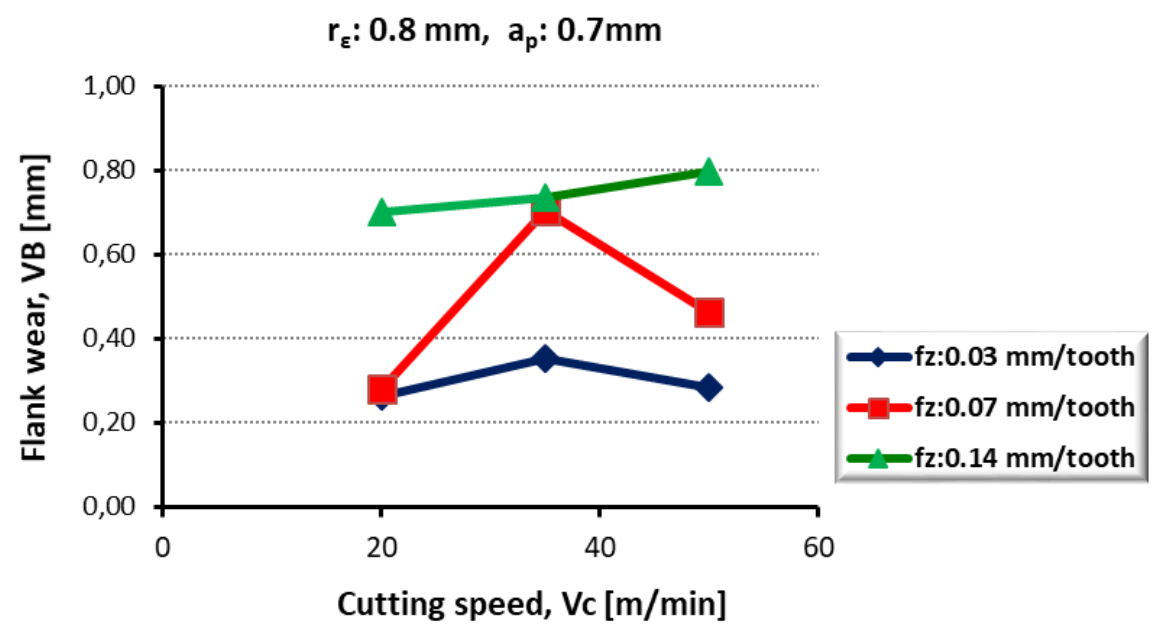

Figure 16. Infographic of flank wear that occurred on cutting tools during the machining of the NiTi shape memory alloy with a $0.8 \mathrm{~mm}$ nose radius tungsten carbide at three different cutting speeds (20, 35 and 50 $\mathrm{m} / \mathrm{min})$ and feed rates $(0.03,0.07$ and $0.14 \mathrm{~mm} /$ tooth $)$.

Figure 17 and Figure 18 show the flank wear after the machining of NiTi shape memory alloys with two different nose radii $(0.4 \mathrm{~mm}$ and $0.8 \mathrm{~mm})$ at three different cutting speeds and feed rates. The maximum flank wear was achieved by tungsten carbide tools with a nose radius of $0.4 \mathrm{~mm}$ at cutting speed of $50 \mathrm{~m} / \mathrm{min}$ and a feed rate of $0.14 \mathrm{~mm} /$ tooth $(0.942 \mathrm{~mm})$. The minimum flank wear was achieved with the tungsten carbide tools of $0.8 \mathrm{~mm}$ nose radius at a cutting speed of $20 \mathrm{~m} / \mathrm{min}$ and a feed rate of $0.03 \mathrm{~mm} /$ tooth $(0.264 \mu \mathrm{m})$. Flank wear depends on the cutting speed and was 0.627 $\mathrm{mm}$ at $20 \mathrm{~m} / \mathrm{min}, 0.785 \mathrm{~mm}$ at $50 \mathrm{~m} / \mathrm{min}$, and $0.813 \mathrm{~mm}$ at $35 \mathrm{~m} / \mathrm{min}$. It was about $30 \%$ lower for tungsten carbide tools with the nose radius of $0.8 \mathrm{~mm}$. The higher levels of wear in the small nose cutting tool have been attributed to the low strength of the cutting edge with lower radius [42-45, 53, 69-74]. 

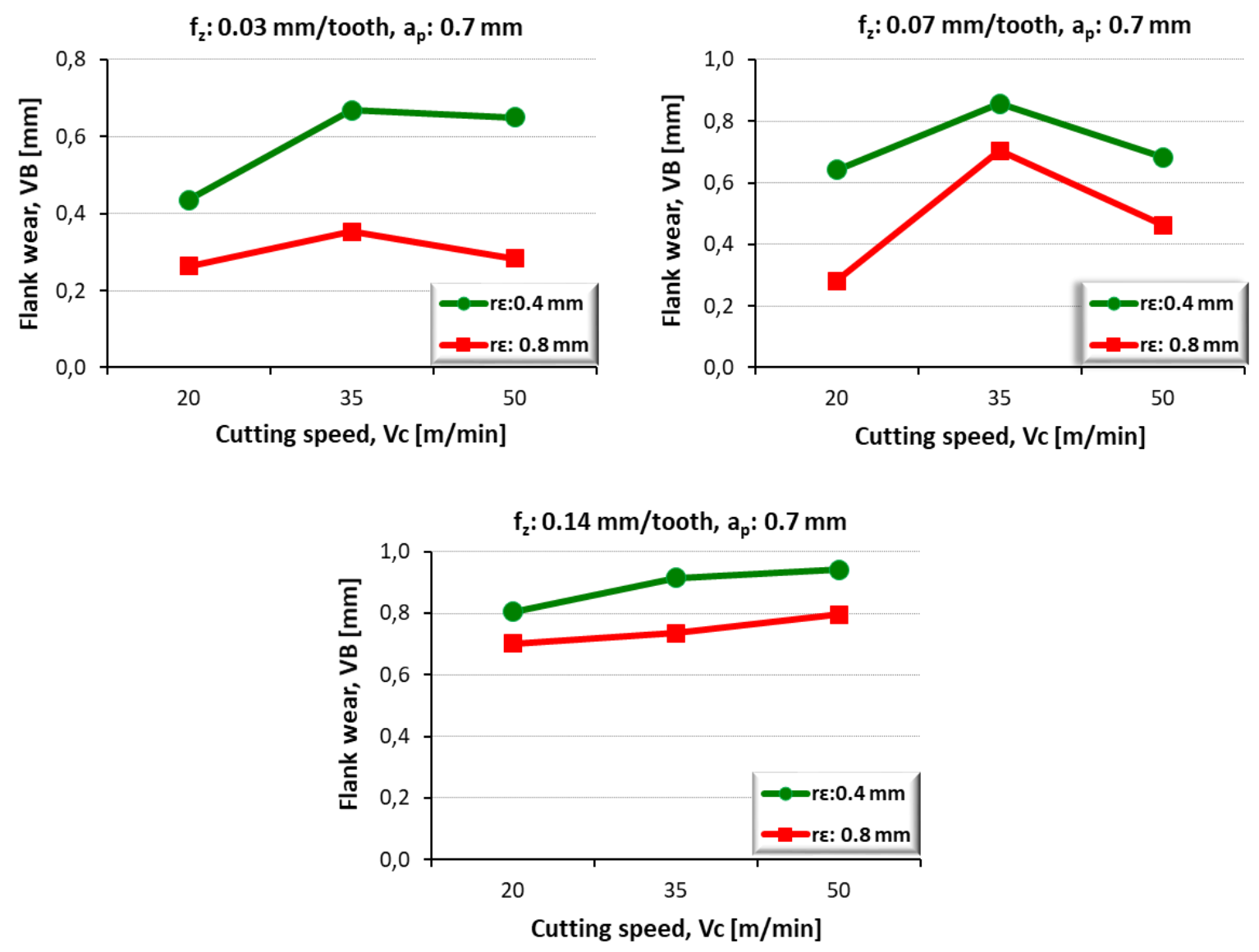

Figure 17. Flank wear of tungsten carbide tools with two different nose radii $(0.4 \mathrm{~mm}$ and $0.8 \mathrm{~mm})$ after the machining of the NiTi shape memory alloy with two different nose radii at three different cutting speeds (20, 35 and $50 \mathrm{~m} / \mathrm{min})$.

Figure 18 shows that the flank wear of cutting tool with a $0.4 \mathrm{~mm}$ nose radius was $0.584 \mathrm{~mm}$ at $0.03 \mathrm{~mm} /$ tooth, $0.727 \mathrm{~mm}$ at $0.07 \mathrm{~mm} /$ tooth, and $0.887 \mathrm{~mm}$ at $0.14 \mathrm{~mm} /$ tooth. When the nose radius was $0.8 \mathrm{~mm}$, flank wear decreased. These results confirm that the nose radius of the cutting tool is an important factor during the chip removal process. The cutting tool with higher nose radius creates a larger contact area with the workpiece, and a larger contact area means higher friction and thus an increase in the workpiece surface temperature. As a result, the workpiece material softens, while the cutting tools can keep their hardness at high temperatures [28-33, 40]. Less tool wear and better tool life of the cutting tool with higher nose radius have been attributed to high strength of the cutting edge [45-48, 70-75]. The maximum flank wear as a result of the cutting process of the NiTi shape memory alloy was obtained when the cutting tools had a nose radius of $0.4 \mathrm{~mm}$, while the minimum flank wear was obtained when the cutting tools had a nose radius of $0.8 \mathrm{~mm}$. 

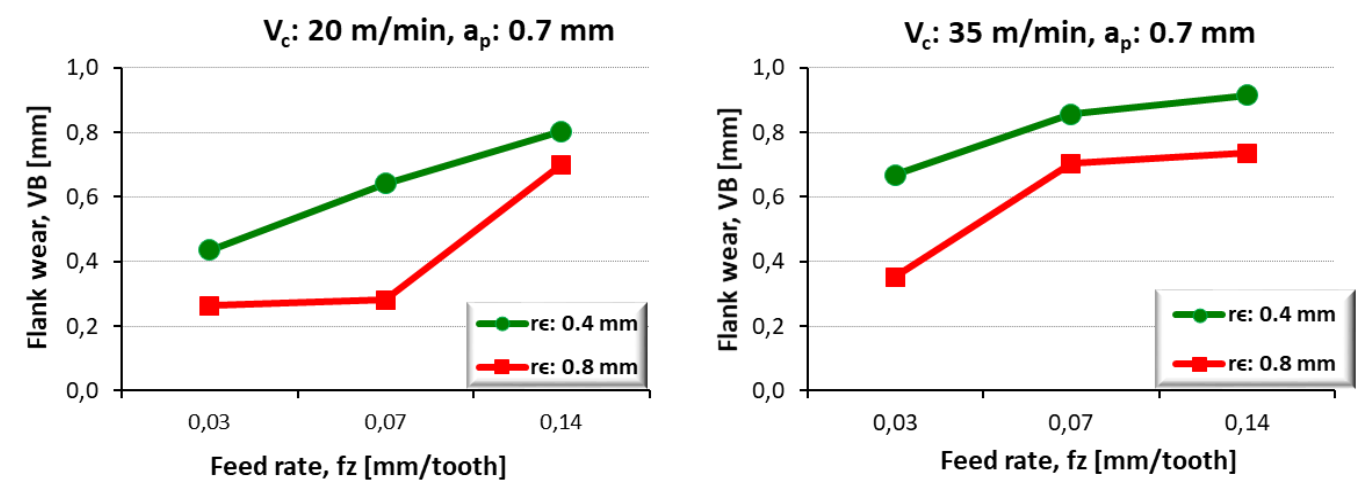

$V_{c}: 50 \mathrm{~m} / \mathrm{min}, a_{\mathrm{p}}: 0.7 \mathrm{~mm}$

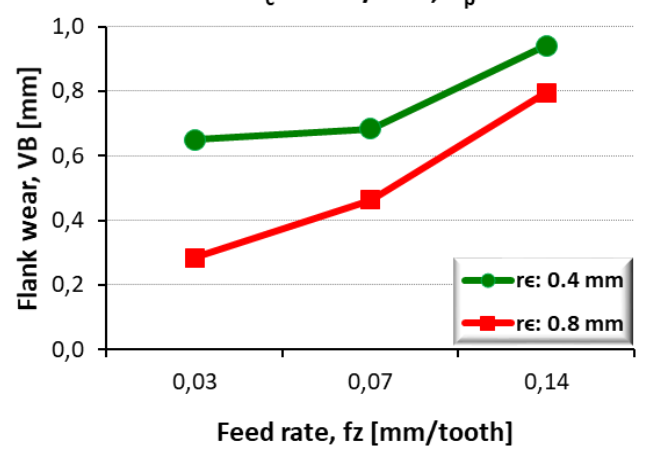

Figure 18. Flank wear of tungsten carbide tools of two different nose radii $(0.4 \mathrm{~mm}$ and $0.8 \mathrm{~mm})$ during the machining of the NiTi shape memory alloy at three different feed rates $(0.03,0.07$ and $0.14 \mathrm{~mm} /$ tooth $)$.

\section{Conclusions}

In this study, the average surface roughness values of workpiece were investigated during the surface milling of the NiTi shape memory alloy using the cutting tools of different nose radii at dry cutting conditions. The results of the performance tests are as follows:

1. The types of tool wear and damages observed on cutting tools during the cutting tests were found to be flank wear, BUE formation and fracture caused by mechanical fatigue.

2. Flank wear was taken into consideration to compare the lifetime of cutting tools at different machining parameters.

3. It was determined that increasing cutting speed and feed rate in general increases flank wear on the cutting tool.

4. We analysed the cutting tools with two different nose radii $(0.4 \mathrm{~mm}$ and $0.8 \mathrm{~mm})$ and we found that the lifetime of cutting tools with nose radius of $0.8 \mathrm{~mm}$ was approximately $34 \%$ higher at 20 $\mathrm{m} / \mathrm{min}$ cutting speed and $0.03 \mathrm{~mm} /$ tooth feed rate.

5. The correlation between feed rate and average surface roughness is linear, and the average surface roughness increases with increasing feed rate.

6. Cutting speed and average surface roughness are inversely proportional. Increasing the cutting speed enhances surface roughness.

7. We found that the nose radius of cutting tool and feed rate have a significant effect on surface roughness.

8. Flank wear on the cutting tool adversely affects surface roughness.

9. Minimum surface roughness $(0.346 \mu \mathrm{m})$ was achived at $20 \mathrm{~m} / \mathrm{min}$ cutting speed and 0.03 $\mathrm{mm} /$ tooth feed rate using the cutting tools with $0.8 \mathrm{~mm}$ nose radius.

Author Contributions: Performed and designed the experiments, E.A., and H.G.; verification experiments and wrote the paper, E.A., and H.G; revised the paper and supervised the whole 
research, E.A., and H.G; analyzed the data, E.A., H.G., and D.O. All authors have read and agreed to the published version of the manuscript.

Funding: This research received no external funding

Acknowledgements: The installation of the materials and the experimental setup used in the study was conducted with Karabük University BAP Project No FDK-2020-2197. The authors would like to thank Karabük University, BAP Project Unit for their support.

Conflicts of Interest: The authors declare no conflict of interest. 


\section{References}

1. Matveenko, V.P., M.A. Yurlov, and N.A. Yurlova. Optimization of the Damping Properties of ElectroViscoelastic Objects with External Electric Circuits, in Mechanics of Advanced Materials: Analysis of Properties and Performance, V.V. Silberschmidt and V.P. Matveenko, Editors. Springer Switzerland, 2015.

2. Choi, S.B. Position control of a single-link mechanism activated by shape memory alloy springs: Experimental results, Smart Mater. Struct, 2006, 15, 1, 1551-58.

3. Kaynak, Y., et al., Surface Characteristics of Machined NiTi Shape Memory Alloy: The Effects of Cryogenic Cooling and Preheating Conditions. Journal of Materials Engineering and Performance, 2017. 26(7): p. 3597-3606.

4. Guo, Y., et al. Machinability and surface integrity of Nitinol shape memory alloy. CIRP Annals, 2013. 62(1): p. 83-86.

5. Kuppuswamy, R. and A. Yui. High-speed micromachining characteristics for the NiTi shape memory alloys. The International Journal of Advanced Manufacturing Technology, 2017. 93(1): p. 11-21.

6. Huang, H., H.Y. Zheng, and Y. Liu. Experimental investigations of the machinability of Ni 50.6 Ti 49.4 alloy. Smart Materials and Structures, 2005. 14(5): p. S297

7. Hung, C.-H., et al. Micromachining NiTi tubes for use in medical devices by using a femtosecond laser. Optics and Lasers in Engineering, 2015. 66: p. 34-40

8. Fu, C.H., Y.B. Guo, and M.P. Sealy. A predictive model and validation of laser cutting of nitinol with a novel moving volumetric pulsed heat flux. Journal of Materials Processing Technology, 2014. 214(12): p. 2926-2934.

9. Fu, C.H., et al. A Comparative Study on White Layer Properties by Laser Cutting vs. Electrical Discharge Machining of Nitinol Shape Memory Alloy. Procedia CIRP, 2016. 42(Supplement C): p. 246251

10. Fu, C.H., et al. Finite element simulation and experimental validation of pulsed laser cutting of nitinol. Journal of Manufacturing Processes, 2015. 19(Supplement C): p. 81-86.

11. Li, C., S. Nikumb, and F. Wong. An optimal process of femtosecond laser cutting of NiTi shape memory alloy for fabrication of miniature devices. Optics and Lasers in Engineering, 2006. 44 (10): p. 1078-1087.

12. Mehrpouya, M., A. Gisario, and M. Elahinia. Laser welding of NiTi shape memory alloy: A review. Journal of Manufacturing Processes, 2018. 31: p. 162-186

13. Pfeifer, R., et al. Pulsed Nd:YAG laser cutting of NiTi shape memory alloys Influence of process parameters. Journal of Materials Processing Technology, 2010. 210(14): p. 1918-1925.

14. Quintino, L., et al. Cutting NiTi with Femtosecond Laser. Advances in Materials Science and Engineering, 2013.

15. Saedi, S. Shape Memory Behavior of Dense and Porous NiTi Alloys Fabricated by Selective Laser Melting, in Mechanical Engineering., University of Kentucky: Lexington, Kentucky, 2017. p. 170.

16. Uppal, N. and P.S. Shiakolas. Micromachining Characteristics of NiTi Based Shape Memory Alloy Using Femtosecond Laser. Journal of Manufacturing Science and Engineering, 2008. 130(3): p. 031117031117-7.

17. Hsieh, S.F., et al. EDM surface characteristics and shape recovery ability of Ti35.5Ni48.5Zr16 and Ni60A124.5Fe15.5 ternary shape memory alloys. Journal of Alloys and Compounds, 2013. 
18. Theisen, W. and A. Schuermann. Electro discharge machining of nickel-titanium shape memory alloys. Materials Science and Engineering: A, 2004. 378(1): p. 200-204.

19. Abedi, E., S. Daneshmand, and R. Hessami. Analysis of Tool Kind Effect on Material Removal Rate in Nickel Titanium Smart Alloy. Vol. 10. 2013. 944-949.

20. Al-Ahmari, A.M.A., et al. A Hybrid Machining Process Combining Micro-EDM and Laser Beam Machining of Nickel-Titanium-Based Shape Memory Alloy. Materials and Manufacturing Processes, 2016. 31(4): p. 447-455.

21. Daneshmand, S., V. Monfared, and A.A. Lotfi Neyestanak. Effect of Tool Rotational and $\mathrm{Al}_{2} \mathrm{O}_{3} \mathrm{Powder}$ in Electro Discharge Machining Characteristics of NiTi-60 Shape Memory Alloy. Silicon, 2017. 9(2): p. 273-283.

22. Gaikwad, V. and V.S. Jatti. Optimization of material removal rate during electrical discharge machining of cryo-treated NiTi alloys using Taguchi's method. Journal of King Saud University Engineering Sciences, 2016.

23. Hsieh, S.F., et al. The machining characteristics and shape recovery ability of $\mathrm{Ti}-\mathrm{Ni}-\mathrm{X}(\mathrm{X}=\mathrm{Zr}, \mathrm{Cr})$ ternary shape memory alloys using the wire electro-discharge machining. International Journal of Machine Tools and Manufacture, 2009. 49(6): p. 509-514.

24. Huang, T.-S., et al. Surface modification of TiNi-based shape memory alloys by dry electrical discharge machining. Journal of Materials Processing Technology, 2015. 221: p. 279-284.

25. Jahan, M.P., P. Kakavand, and F. Alavi. A Comparative Study on Micro-electro-discharge-machined Surface Characteristics of $\mathrm{Ni}-\mathrm{Ti}$ and $\mathrm{Ti}-6 \mathrm{Al}-4 \mathrm{~V}$ with Respect to Biocompatibility. Procedia Manufacturing, 2017. 10: p. 232-242.

26. Liu, J.F., L. Li, and Y.B. Guo. Surface Integrity Evolution from Main Cut to Finish Trim Cut in W-EDM of Shape Memory Alloy. Procedia CIRP, 2014. 13(Supplement C): p. 137-142.

27. LotfiNeyestanak, A.A. and S. Daneshmand. The Effect of Operational Cutting Parameters on Nitinol60 in Wire Electrodischarge Machining. Advances in Materials Science and Engineering, 2013: p. 1-6.

28. Majumder, H. and K. Maity. Prediction and optimization of surface roughness and micro-hardness using grnn and MOORA-fuzzy-a MCDM approach for nitinol in WEDM. Measurement, 2018. 118: p. $1-13$.

29. Manjaiah, M., et al. Effect of electrode material in wire electro discharge machining characteristics of Ti50Ni50-xCux shape memory alloy. Precision Engineering, 2015. 41: p. 68-77.

30. Sharma, N., T. Raj, and K.K. Jangra. Parameter optimization and experimental study on wire electrical discharge machining of porous Ni40Ti60 alloy. Proceedings of the Institution of Mechanical Engineers, Part B: Journal of Engineering Manufacture, 2017. 231(6): p. 956-970.

31. Jatti, V.S. and T.P. Singh. Effect of deep cryogenic treatment on machinability of NiTi shape memory alloys in electro discharge machining. 2014. p. 197-201.

32. Lee, E.S. and T.H. Shin. An evaluation of the machinability of nitinol shape memory alloy by electrochemical polishing. Journal of Mechanical Science and Technology, 2011. 25(4): p. 963.

33. Kong, M.C., D. Axinte, and W. Voice. Challenges in using waterjet machining of NiTi shape memory alloys: An analysis of controlled-depth milling. Journal of Materials Processing Technology, 2011. 211(6): p. 959-971.

34. Kong, M.C., et al. On geometrical accuracy and integrity of surfaces in multi-mode abrasive waterjet machining of NiTi shape memory alloys. CIRP Annals, 2013. 62(1): p. 555-558.

35. Kaynak, Y., H. Karaca, and I.s. Jawahir. Cryogenic Machining of NiTi Shape Memory Alloys. 2011. 
36. Kowalczyk, M. Application of Taguchi method to optimization of surface roughness during precise turning of NiTi shape memory alloy in Photonics Applications in Astronomy, Communications, Industry, and High-Energy Physics Experiments, SPIE, 2017.

37. Chockalingam, S., U. Natarajan, and S. Kalyana Sundaram. Modeling and Optimization of Tool Wear in a Passively Damped Boring process using Response Surface Methodology. Transactions of the Indian Institute of Metals, 2016. 69(7): p. 1443-1448.

38. Kaynak, Y. Machining and Phase Transformation Response of Room-Temperature Austenitic NiTi Shape Memory Alloy. Journal of Materials Engineering and Performance, 2014. 23(9): p. 3354-3360.

39. Kaynak, Y., et al. Surface Characteristics of Machined NiTi Shape Memory Alloy: The Effects of Cryogenic Cooling and Preheating Conditions. Journal of Materials Engineering and Performance, 2017. 26(7): p. 3597-3606.

40. Kaynak, Y., H.E. Karaca, and I.S. Jawahir. Surface Integrity Characteristics of NiTi Shape Memory Alloys Resulting from Dry and Cryogenic Machining. Procedia CIRP, 2014. 13(Supplement C): p. 393398.

41. Kaynak, Y., et al. Analysis of Tool-wear and Cutting Force Components in Dry, Preheated, and Cryogenic Machining of NiTi Shape Memory Alloys. Procedia CIRP, 2013. 8(Supplement C): p. 498-503.

42. Kaynak, Y., et al. Tool-wear analysis in cryogenic machining of NiTi shape memory alloys: A comparison of tool-wear performance with dry and MQL machining. Wear, 2013. 306(1): p. 51-63.

43. Kaynak, Y., S. Manchiraju, and I.S. Jawahir. Modeling and Simulation of Machining-induced Surface Integrity Characteristicsof NiTi Alloy. Procedia CIRP, 2015. 31(Supplement C): p. 557-562.

44. Kaynak, Y., et al. Progressive tool-wear in machining of room-temperature austenitic NiTi alloys: The influence of cooling/lubricating, melting, and heat treatment conditions. Journal of Materials Processing Technology, 2015. 215(Supplement C): p. 95-104.

45. Kaynak, Y., et al. The effects of machining on the microstructure and transformation behavior of NiTi Alloy. Scripta Materialia, 2014. 74(Supplement C): p. 60-63.

46. Kowalczyk, M. Cuting forces during precise turning of NiTi shape memory alloy. Technical Transactions, 2017. 7: p. 137-146.

47. Mehrpouya, M., et al. An investigation on the optimum machinability of NiTi based shape memory alloy. Materials and Manufacturing Processes, 2017. 32(13): p. 1497-1504.

48. Silva, F.V.P.d., et al. Effect of the Cutting Velocity and Heat Treatment on Turning Cutting Forces of an SMA Cu-Al-Be Alloys. Materials Science Forum, 2013. 758: p. 157-164.

49. Weinert, K. and V. Petzoldt. Machining of NiTi based shape memory alloys. Materials Science and Engineering: A, 2004. 378(1): p. 180-184.

50. Weinert, K., V. Petzoldt, and D. Kötter. Turning and Drilling of NiTi Shape Memory Alloys. CIRP Annals, 2004. 53(1): p. 65-68.

51. Biermann, D., et al. A study on micro-machining technology for the machining of NiTi: Five-axis micro-milling and micro deep-hole drilling. Journal of Materials Engineering and Performance, 2011. 20(45): p. 745-751

52. Biermann, D., F. Kahleyss, and T. Surmann. Micromilling of NiTi shape-memory alloys with ball nose cutters. Materials and Manufacturing Processes, 2009. 24(12): p. 1266-1273.

53. Huang, H. A study of high-speed milling characteristics of nitinol. Materials and Manufacturing Processes, 2004. 19(2): p. 159-175. 
54. Piquard, R., et al. Micro-end milling of NiTi biomedical alloys, burr formation and phase transformation. Precision Engineering, 2014. 38(2): p. 356-364.

55. Surmann, T. and E. Krebs. Optimization of Micromilling by Adjustment of Inclination Angles. Procedia CIRP, 2012. 2: p. 87-91.

56. Weinert, K. and V. Petzoldt. Machining NiTi micro-parts by micro-milling. Materials Science and Engineering A, 2008. 481-482(1-2 C): p. 672-675.

57. Zailani, Z.A. and P.T. Mativenga. Effects of Chilled Air on Machinability of NiTi Shape Memory Alloy. Procedia CIRP, 2016. 45(Supplement C): p. 207-210.

58. Kitajima, K., H. Sogabe, and M. Hiromi. Development of shrinking tool holder utilizing of shape memory alloy. Key Engineering Materials, 2005. 291-292: p. 525-530.

59. Lin, H.C., K.M. Lin, and Y.C. Chen. A study on the machining characteristics of TiNi shape memory alloys. Journal of Materials Processing Technology, 2000. 105(3): p. 327-332.

60. Weinert, K., et al. Drilling of NiTi shape memory alloys. Materialwissenschaft und Werkstofftechnik, 2004. 35(5): p. 338-341.

61. Wells, S.,Microdrilling Of Nitinol, in Mechanical Engineering. 2013, Texas A\&M University: Texas. p. 117.

62. Sandvick. Sandvick Coromant Türkiye Ürün Katalogu. SANDVIK COROMANT, 2011.

63. TSE ISO 8688, T.. Frezelemede Takım Ömrü Deneyi-Bölüm 1: Yüzey Frezeleme. Türk Standartları Enstitüsü, 2006

64. Velmurugan, C., V. Senthilkumar, S. Dinesh, ve D. Arulkirubakaran. Machining of NiTi-shape memory alloys-A review. Machining Science and Technology, 2018. 22(3): p. 355-401.

65. Jawahir, I. S., et al. Surface integrity in material removal processes: Recent advances." CIRP annals 60.2 (2011): 603-626.

66. Wang, G, Liu, Z, Ai, X, Huang, W, Niu, J. Effect of cutting parameters on strain hardening of nickeltitanium shape memory alloy, Smart Materials and Structures, 27, 7, 2018.

67. Bhatt, A., Attia, H., Vargas, R., ve Thomson, V. Wear mechanisms of wc coated and uncoated tools in finish turning of inconel 718. Tribology International, 2010 43(5),1113-1121.

68. Li, H., Zeng, H., ve Chen, X. An experimental study of tool wear and cutting force variation in the end milling of inconel 718 with coated carbide cs. Journal of Materials Processing Technology, 2006 180(1),296304.

69. Thakur, D., Ramamoorthy, B., ve Vijayaraghavan, L. Study on the machinability characteristics of superalloy inconel 718 during high speed turning. Materials \& Design, 2009 30(5),1718-1725.

70. Rosnan, R., Azmi, A. I., and Murad, M. N. Effects of Cutting Parameters on Tool Wear and Thrust Force in Drilling Nickel-Titanium (NiTi) Alloys Using Coated and Uncoated Carbide Tools. In Key Engineering Materials, 2018 791, pp. 111-115).

71. H. Caliskan, E. Altas. The effects of cutting conditions on cutting forces in milling of Ti6Al4V alloy, Int. J. Eng. Technol, 2015 13, p.13-22.

72. Caliskan, H., Altas, E., \& Panjan, P. Study of Nanolayer AlTiN/TiN Coating Deposition on Cemented Carbide and its Performance as a Cutting Tool. In Journal of Nano Research, 2017 47, pp. 1-10).

73. Karayel, B.,Nalbant, M. Ç4140 Malzemesinin Tornalamasinda İlerleme, Kesme Hizi Ve Kesici Takimin Yüzey Pürüzlülügü, Takim Ömrü Ve Aşinmaya Etkileri. Makine Teknolojileri Elektronik Dergisi, 2014 11(3), p:11-26. 
74. Taşliyan, A., Acarer, M., Şeker, U., Gökkaya, H., and Demir, B. Inconel 718 Süper Alaşiminin İşlenmesinde Kesme Parameterelerinin Kesme Kuvveti Üzerindeki Etkisi. Gazi Üniversitesi Mühendislik-Mimarlık Fakültesi Dergisi, (2007)22(1).

75. Gökkaya, H., \& Nalbant, M. Kesme hizinin yiğinti katmani ve yiğinti talaş oluşumu üzerindeki etkilerinin SEM ile incelenmesi. Gazi Üniversitesi Mühendislik-Mimarlık Fakültesi Dergisi, (2007), 22(3). 